$\begin{array}{lll}\text { KULTURA } & \begin{array}{l}\text { POLSKA A KADEMIA NAUK } \\ \text { KOMITET SOCJOLOGII }\end{array} & \text { ISSN 0023-5172 } \\ \text { i } & \begin{array}{l}\text { INSTYTUT STUDIÓW POLITYCZNYCH } \\ \text { SPOLECLENSTWO }\end{array} & \\ 2009, \text { nr 1 } & \text { POZA UTARTYM SZLAKIEM }\end{array}$

MACIEJ FRĄCKOWIAK, ŁUKASZ ROGOWSKI

Uniwersytet im. Adama Mickiewicza

\title{
W POSZUKIWANIU POLSKIEJ SOCJOLOGII WIZUALNEJ
}

Każde pisanie o historii z konieczności ją zniekształca — pisze się ją zawsze z konkretnej perspektywy, która po części tylko odtwarza, po części zaś na nowo tworzy swój przedmiot. Nie jest to jednak wystarczający powód, żeby porzucić to zajęcie, tym bardziej że każdy dyskurs potrzebuje swojego języka, bez którego nie może się rozwijać; „każdy”, więc i naukowy. Podobnie jak socjologia wizualna potrzebuje języka, żeby odnaleźć się na planie innych dziedzin i odwołań do historii, które zawsze w jakiś sposób uzasadniają ważność podejmowanego problemu, tak każdy badacz używa jakiegoś języka, który pomaga oswoić i w możliwie najwyższym stopniu zrozumieć dziedzinę, którą zamieszkuje (Geertz 2005, s. 161).

Podejmujemy tu próbę wyłuskania pojęć, za pomocą których autorzy myślą o pewnym obszarze (więc i o jego historii), który starają się pojąć, w celu jego opracowywania. Nie chodzi tu zatem o jakąś ostateczną wizję historii dla samej wartości historycznej, lecz raczej o w miarę klarowne uporządkowanie refleksji, które pomoże wyrysować coś w rodzaju mapy rozważanego przedmiotu, ułatwiającej poruszanie się po jego obszarze (i wykraczanie poza). Niezależnie jednak od osobistych motywacji, aby w ogóle możliwe i uprawnione było pisanie o historii jakiejkolwiek nauki lub jej poszczególnych subdyscyplin, trzeba przyjąć - jak nam się wydaje - przynajmniej trzy wstępne założenia, które będą ukierunkowywać sposób opowiadania o owej historii.

Po pierwsze, trzeba przyjąć, że jakaś subdyscyplina w ogóle istnieje i że ma w miarę ugruntowaną i częściowo przynajmniej zinstytucjonalizowaną (lub chociaż instytucjonalizującą się) pozycję w ramach szeroko rozumianego pola nauki. Po drugie, należy uznać, że owo istnienie i procesy „oswajania” nie są chwilowe, ale istnieją już od jakiegoś czasu — a więc, no właśnie, mają

Adres do korespondencji: Maciej Frąckowiak, os. Stefana Batorego 21/38, 60-687 Poznań, adr@3made.eu; Łukasz Rogowski, Instytut Socjologii UAM, ul. Szamarzewskiego 89, 60-568 Poznań, lukasz.rogowski@gmail.com 
swoją historię. Oba te założenia wyznaczałyby możliwość wymiany doświadczeń pomiędzy badaczami prowadzącymi niezależne od siebie badania, które dotyczą wspólnego im przedmiotu zainteresowań i/lub sposobu ich przeprowadzania. Powstające dzięki temu możliwości metodologicznej intersubiektywizacji wiedzy sprawiają, iż konkretne działania naukowe mogą wyjść poza solipsystyczny świat pojedynczego badacza i właśnie dzięki temu być określone mianem subdyscypliny.

\section{POCZĄTKI INSTYTUCJONALIZACJI}

W 1990 r. Krzysztof Koseła - na łamach „Kultury i Społeczeństwa” opublikował tekst pod tytułem Interpretacja fotografii. Krok ku socjologii wizualnej; wydaje się, że to właśnie przy tej okazji termin „socjologia wizualna” pojawił się $\mathrm{w}$ polskim kontekście publikacyjnym po raz pierwszy. Nie był to jednak pierwszy artykuł wspomnianego autora na temat użycia zdjęć w socjologii. Rok wcześniej, w zbiorowej publikacji Poza granicami socjologii ankietowej, ukazał się tekst Wywiad z interpretacja fotogramów (Koseła 1989). Oba teksty zostały oparte na doświadczeniach autora $z$ badania empirycznego przeprowadzonego przez niego $z$ wykorzystaniem wywiadu fotograficznego. Co istotne, już same tytuły dobrze określają charakter, $w$ jakim debiutowała polska socjologia wizualna: w roli jakościowej metody badawczej.

Dziesięć lat później Krzysztof Olechnicki opublikował artykuł pod tytułem Obraz i wizualność w naukach społecznych (Olechnicki 1999), poszerzając zapoczątkowaną przez Kosełę perspektywę patrzenia na socjologię/antropologię wizualną, i to zarówno w kontekście metod, jak i przedmiotu refleksji teoretycznej. W ten sposób do fotografii jako metody badawczej została dołączona wizualność jako istotny, a więc domagający się socjologicznej refleksji wymiar życia społecznego (chociaż Olechnicki pozostawił ten wątek zdecydowanie w cieniu rozważań o metodach). Charakterystyczne metody i przedmiot - oba sposoby myślenia o socjologii wizualnej wyznaczają do dzisiaj jej ogólne ramy.

W okolicach 2000 r. pojawiły się kolejne artykuły, między innymi: Antropologiczna penetracja wizualnych przestrzeni rzeczywistości: fotografia jako narzędzie badawcze (Olechnicki 2000); Socjologia obrazu, socjologia fotografii - praktyki badawcze (Ferenc 2001); Wywiad z użyciem fotografii w metodologii badań socjologicznych $i$ w praktyce społecznej (Olechnicki, Szlendak 2002); Poznań $w$ fotografii $i$ świadomości swoich mieszkańców (Kaczmarek 2002). Ten ostatni tym bardziej wart wspomnienia, że napisany z perspektywy doświadczeń badawczych wyniesionych $z$ jednego $z$ pierwszych $w$ Polsce projektów bezpośrednio wykorzystujących $\mathrm{w}$ procesie badawczym metody socjologii wizualnej, a konkretnie wywiad fotograficzny z użyciem zdjęć wykonanych do celów badania przez samych respondentów (autofotografia).

W roku 2003 została wydana pierwsza monografia, niezwykle istotna, bo stanowiąca próbę zdecydowanie pełniejszego rozliczenia się $z$ tematyką ob- 
razu w naukach społecznych, zdająca relację ze wspólnych korzeni obu wspomnianych obszarów i związków, które między nimi zachodzą. Mowa o Antropologii obrazu Krzysztofa Olechnickiego (2003a), książce, którą przynajmniej $z$ dwóch powodów można uznać za kolejny krok milowy w kierunku popularyzacji obrazu w socjologii: po pierwsze - był to pierwszy systematyczny wkład w refleksję, przywołujący ogromną liczbę pomysłów autorstwa zagranicznych teoretyków dziedziny, po drugie - do czasu publikacji Antropologii artykuły o omawianej w niej tematyce ukazywały się wyłącznie na łamach czasopism naukowych (głównie „Kultury i Społeczeństwa” oraz „Przeglądu Socjologicznego"), tymczasem od 2003 r. Antropologię obrazu można już było spotkać, nawet przypadkiem, na półce $\mathrm{w}$ księgarni ${ }^{1}$.

Rok później swoją pierwszą książkę - Fotografia. Dyletanci, amatorzy i artyści - wydał Tomasz Ferenc (2004b). Warto o niej pamiętać choćby dlatego, że jest to praca oparta na wynikach prowadzonych przez tego autora badań łączących techniki ilościowe z jakościowymi (bezpiecznie będzie założyć, że były to pierwsze w Polsce socjologiczne badania porównawcze środowiska fotograficznego), jak również ze względu na fakt, że — tak jak rok wcześniej Antropologia obrazu - została ona wyróżniona przez Polskie Towarzystwo Socjologiczne Nagrodą im. Stanisława Ossowskiego (co wolno traktować jako dowód akceptacji tematyki i sposobu jej opracowywania przez zinstytucjonalizowany wymiar polskiego środowiska socjologicznego).

W tym samym roku, w którym wydano książkę Olechnickiego (2003), w Instytucie Socjologii UAM zorganizowano pierwszą w Polsce konferencję naukową w całości poświęconą socjologii wizualnej — „Kadrowanie rzeczywistości" - której rezultatem była książka pod takim samym tytułem (Kaczmarek 2004). Podejmowano przy tej okazji pierwsze próby określenia, czym jest socjologia wizualna, jakich metod używa, eksperymentowano z narracjami wizualnymi jako formą wypowiedzi naukowej. Rok po tej konferencji, również w Poznaniu, ale po raz pierwszy w ramach Ogólnopolskiego Zjazdu Polskiego Towarzystwa Socjologicznego, odbyła się sesja naukowa poświęcona omawianej tematyce ${ }^{2}$. Wygłoszone w niej referaty stały się podstawą dla ko-

${ }^{1}$ Warto dodać, że w tym samym roku co Antropologia obrazu, i pod redakcją tego samego autora, ukazała się również pierwsza w Polsce zbiorowa publikacja poświęcona omawianej tematyce Obrazy $w$ działaniu. Studia $z$ socjologii $i$ antropologii obrazu (Olechnicki 2003b). Obie książki warto czytać razem, ponieważ — jak zwraca uwagę Hubert Czachowski (2004, s. 206) — „o ile pierwsza pomyślana jest jako teoretyczny antropologiczno-socjologiczny wykład na tematy podstawowe", o tyle druga jako „próba przełożenia teorii na opisy zjawisk kultury”.

$2 \mathrm{Na}$ ostatnim z dotychczasowych Zjazdów (Zielona Góra, 2007) socjologii wizualnej poświęcono już dwie sesje („Socjologia wizualna w praktyce badawczej”, organizowana przez Jerzego Kaczmarka, oraz „Obrazy w sieci”, pod kierunkiem Krzysztofa Olechnickiego i Tomasza Ferenca), obie zakończone publikacjami książkowymi (Kaczmarek 2008; Ferenc, Olechnicki 2008). 
lejnej książki: Co widać? (Kaczmarek, Krajewski 2006), pogłębiającej refleksję rozpoczętą Kadrowaniem ${ }^{3}$.

W 2006 r. ukazała się również monografia autorstwa Piotra Sztompki Socjologia wizualna. Fotografia jako metoda badawcza. Jej znaczenia nie sposób przecenić, przede wszystkim ze względu na autorytet naukowy autora, który sprawił choćby tyle, że hasło „socjologia wizualna” jest dzisiaj obecne w każdym katalogu bibliotecznym i nie sposób go nie zauważać lub ignorować.

Dokonując przeglądu publikacji nie sposób nie wspomnieć także o internetowym czasopiśmie naukowym „Ikonosfera” (www.ikonosfera.umk.pl), redagowanym w Instytucie Socjologii UMK, i poświęconym antropologii i socjologii wizualnej (pierwszy numer ukazał się w 2006 r., kolejny w 2008). Pod koniec 2008 r. ukazał się również kolejny numer „Przeglądu Socjologii Jakościowej”, wart przywołania, ponieważ był jednocześnie pierwszym w Polsce numerem prestiżowego czasopisma ogólnosocjologicznego w całości poświęconym technikom socjologii/antropologii wizualnej ${ }^{4}$.

Z historii bardziej instytucjonalnej, a nie publikacyjnej, trzeba wspomnieć o utworzeniu w 2000 r. Pracowni Socjologii Wizualnej przy Instytucie Socjologii UAM, której pomysłodawcą i kierownikiem był Jerzy Kaczmarek. W 2007 r. Pracownia została przekształcona w Zakład Badań Kultury Wizualnej i Materialnej, pod kierownictwem Marka Krajewskiego. Warto natomiast wspomnieć, że dotychczas nie powstała żadna ogólnopolska organizacja bądź sekcja naukowa, która w sposób instytucjonalny grupowałaby naukowców zainteresowanych w swej pracy wizualnością. Dla porównania - Międzynarodowe Towarzystwo Socjologii Wizualnej (IVSA) powstało już w $1983 \mathrm{r}$.

Istotnym elementem było również uruchomienie w Instytucie Socjologii UAM kursu specjalizacyjnego „socjologia wizualna” (w 2005 r.), w którego programie znajdują się takie przedmioty jak: obraz i wizualność w kulturze Zachodu, historia fotografii socjologicznej, ilościowe i jakościowe metody analizy obrazu, historia filmu socjologicznego, obraz w interakcjach społecznych, cyfrowe techniki fotografowania/filmowania oraz montażu. W Instytutach Socjologii UMK i UŁ oraz w Instytucie Stosowanych Nauk Społecznych UW w programie studiów znajdują się odpowiednio „antropologia obrazu”, „socjologia fotografii” i „antropologia wizualna”. Instytut Etnologii i Antropolo-

${ }^{3}$ Przy okazji sesji naukowej zorganizowano również wystawę zatytułowaną „Zasiedzenie” (kurator: Marek Krajewski). Pokazane zostały na niej prace artystów, którzy w swoich zdjęciach podejmowali problem prywatnych przestrzeni, sposobów ich modyfikacji i przekształceń, pochylali się nad ich estetyką. Wystawę i konferencję warto czytać razem, pamiętając, że taką próbę konfrontowania spojrzeń socjologów i fotografów patrzących na społeczeństwo da się wpisać w dłuższą historię podobnych inicjatyw, mających w Polsce miejsce przynajmniej od lat osiemdziesiątych.

${ }^{4}$ Redakcja „Kultury i Społeczeństwa” planuje poświęcenie w roku 2010 całego numeru omawianej tematyce, lecz w szerszym kontekście kultury wizualnej, a nie tylko metodologii. Numer otwierać będzie Kwestionariusz Kultury Wizualnej, jako wstęp do ogólnokrajowej, interdyscyplinarnej dyskusji na temat statusu i badań kultury wizualnej w Polsce. 
gii Kulturowej UW oferuje przedmiot „wprowadzenie do antropologii wizualnej”. Z kolei na socjologii UJ prowadzone są zarówno przedmioty kursowe, jak i obozy badawcze związane z socjologią wizualną.

Tematyka wizualna coraz popularniejsza jest również w studenckim ruchu naukowym. Na przykład w Poznaniu istnieje Warsztat Socjologii Wizualnej (www.warsztatywizualne.blogspot.com) - drugi, po Zakładzie Badań Kultury Wizualnej i Materialnej, spadkobierca Pracowni Socjologii Wizualnej. W Białymstoku działa Koło Antropologii Obrazu, a przy Naukowym Kole Socjologicznym na Uniwersytecie Gdańskim — sekcja wizualna „SPOT”.

\section{KŁOPOTY Z AUTODEFINICJA}

Na początku artykułu sygnalizowaliśmy, że istnieje również trzeci warunek, który musi być spełniony, żeby można było mówić o historii subdyscypliny. Warunek najtrudniejszy, w szczególności w odniesieniu do tych obszarów i tradycji badawczych, które można określić mianem „młodych”. Jest nim ujednolicony sposób rozumienia subdyscypliny i co za tym idzie — odnoszenie jej pojęciowej nazwy do tego samego desygnatu. Nie chodzi przy tym oczywiście o próbę odgórnego, instytucjonalnego decydowania o tym, co jest, a co nie jest „prawdziwą" i „pełnoprawną" socjologią wizualną. Chodzi raczej o stwierdzenie, że podobnie jak subdyscyplina nie rodzi się wraz $z$ jej nazwaniem, tak i jej historia jest opisem nie tylko różnego rodzaju badań, książek, artykułów, kursów akademickich i spotkań naukowych, lecz również (a może przede wszystkim) swoistą metaopowieścią, na wspomnianych wydarzeniach opartą, mającą na celu przede wszystkim pokazanie dróg wypracowywania pewnej lokalnej (w tym przypadku - polskiej) wspólnoty naukowej i zgody na sposób mówienia o subdyscyplinie, opisywania badań $z$ nią związanych i w jej ramach prowadzonych.

Gdyby oprzeć się wyłącznie na polskich doświadczeniach, doszlibyśmy najpewniej do przekonania, że socjologia wizualna jako subdyscyplina wprawdzie istnieje (na przykład jako lokalna nazwa pewnych przedsięwzięć dydaktycznych), lecz przynajmniej do niedawna znajdowała się w stanie częściowego rozkładu pojęciowo-tematycznego. Już tytuły książek i artykułów sugerować mogą taki stan. Ten sam lub bardzo podobny kontekst jest bowiem określany bądź to jako „socjologia wizualna” — jak w przypadku Piotra Sztompki lub osób związanych z Instytutem Socjologii UAM, bądź „antropologia obrazu”, który to termin, zaproponowany przez Krzysztofa Olechnickiego, stosowany jest w środowisku toruńskim i warszawskim; albo też „socjologia obrazu”/,fotografii”, w wydaniu Tomasza Ferenca (2001).

Obok tych pojęć można się spotkać ze „studiami wizualnymi” (visual studies), , antropologią wizualną” (visual antropology), „antropologią obrazu” (w znaczeniu Bild Anthropologie; Belting 2007), new art history, „studiami medioznawczymi” (media studies), visual culture, „socjologią filmu”, „etnografią wizualną” 
itd. Na problem nazw już dziesięć lat temu zwracał uwagę Olechnicki (1999), dostrzegając w nim jednak głównie brak translatorskiej elegancji oraz sądząc, że odpowiedni przekład rozwiąże sprawę. Tymczasem polscy badacze proponowali nie tylko kalki językowe - jak w przypadku "socjologii wizualnej”, ale również mniej dosłowne przekłady - na przykład "antropologia obrazu” i „socjologia fotografii”; problem jednak pozostał.

Tak czy inaczej zamienne stosowanie pojęć importowanych na polski grunt $z$ anglo- i niemieckojęzycznych tekstów sprawiło, iż socjologia wizualna rozmywa się do pewnego stopnia w bardzo szerokim kontekście, obejmującym, po pierwsze, różne formy refleksji nad współczesną (i nie tylko) kulturą wizualną, a po drugie - różnego rodzaju rozwiązania metodologiczne wykorzystujące $\mathrm{w}$ badaniach empirycznych materiały wizualne. Podejmowane kilka lat temu w ramach socjologii wizualnej próby pojęciowo-teoretycznego uporządkowania były $z$ konieczności kontekstualne, formułowane bardziej jako propozycje niż podsumowania, z zastrzeżeniem ich „szkicowego” charakteru (zob. np. Ferenc 2001; Drozdowski 2004; Herudziński 2006; Sztompka 2006). Nie mogło być zresztą inaczej - nikt raczej nie zaczynał pisania o socjologii wizualnej z przepowiednią ogólnego planu dla dyscypliny w głowie; mieliśmy raczej do czynienia z kiełkowaniem różnych pomysłów teoretycznych i podejść badawczych. Inspirowano się przy tym nie tylko tekstami, które dzisiaj bylibyśmy skłonni określić jako wchodzące w zakres socjologii/antropologii wizualnej. $\mathrm{Na}$ własną rękę doszukiwano się inspiracji w semiotyce, semiologii, ikonologii, fenomenologii czy krytycznych teoriach dyskursu. Nie pomogło to w budowie wspólnego i zrozumiałego dla pozostałych socjologów języka ${ }^{5}$.

Wydaje się jednak, że dzisiaj mamy już wystarczająco dużo książek, projektów badawczych, filmów i konferencji, żeby móc pokusić się o uporządkowanie pola, co umożliwi pisanie jego historii. Są ku temu przynajmniej dwie przesłanki. Po pierwsze, polscy badacze zaczęli uczestniczyć we wspólnych, międzyuczelnianych projektach, co w oczywisty sposób skutkuje bardziej bezpośrednią wymianą doświadczeń oraz uzgadnianiem (a przynajmniej uwzględnianiem) wzajemnych pomysłów na socjologię wizualną. Po drugie, wydaje się, że polska wersja socjologii wizualnej zaczyna przypominać swój zachodni odpowiednik w próbach opuszczenia specjalizacyjnej niszy, do której (trochę na własne życzenie) ją redukowano; dąży do ewaluacji teoretycznego i pojęciowego zaplecza badań wizualnych, zaczyna w końcu tworzyć otwarte bazy

${ }^{5}$ Oczywiście podobne uwagi można uczynić wobec całej socjologii, wszystkich jej teorii i subdyscyplin. Jest to skutkiem jej wieloparadygmatycznej natury. Paradoksalnie zatem, procesy, które dają się zaobserwować w socjologii wizualnej, uznać można za symptomy rozwoju, a nie kryzysu. Różnicuje się ona wewnętrznie, wytwarza różne metodologie, pojęcia stosuje coraz bardziej świadomie. Innymi słowy, „dojrzewa” jako element socjologii ogólnej, w której poszczególne podejścia teoretyczne dążą do wytworzenia w miarę spójnych założeń i podejmowanych tematów, wypracowując $\mathrm{w}$ tym celu różne słowniki pojęć właśnie po to, żeby potem móc uczynić z nich podstawę do odróżniania się od innych kontekstów teoretycznych. 
danych wizualnych (wspierające rozwój i testowanie teorii), stara się też projektować definicje „najlepszych praktyk” w badaniach wizualnych (zob. np. Kaczmarek 2008). Innymi słowy, robi wszystko to, do czego zachęca John Grady w tekście pod wiele mówiącym tytułem Badania wizualne na rozdrożu (2009).

\section{KORZENIE POMYSŁÓW}

Co się tyczy korzeni socjologii wizualnej, to John Grady (2007, s. 63) wskazuje na dwa kluczowe impulsy: pierwszym jest przekonanie o użyteczności metod wizualnych $\mathrm{w}$ badaniach nad społeczeństwem i kulturą, drugi sięga dużo głębiej i wiąże się z charakterystycznym dla zachodniej kultury zainteresowaniem reprezentacjami wizualnymi. Zacznijmy od pierwszego $z$ nich.

Historia wykorzystania fotografii jako metody badawczej sięga niemalże jej początków i chociaż socjologię i fotografię „wynaleziono” prawie w tym samym roku (odpowiednio, w 1837 i 1839), to jednak historia ich bliższych, bardziej sprofesjonalizowanych związków zacznie się zdecydowanie później (na dobre dopiero w latach siedemdziesiątych XX wieku; zob. np. Becker 1974; Goffman 1979). Prawie natychmiast po wynalezieniu fotografii zdjęciami podpierali swoje tezy antropolodzy; socjolodzy również używali obrazów, ale nie zdjęć, raczej map, i nie w procesie badawczym, ale w celach ilustracyjnych.

Antropologii zdecydowanie należy się zatem kilka zdań więcej, i to bynajmniej nie ze względu (i nie na temat) pierwszych eksperymentów, które z dzisiejszej perspektywy bardziej niż socjologów wizualnych interesują raczej historyków fotografii i krytyków kolonialnej antropologii. Nie sposób o niej nie wspomnieć przede wszystkim w kontekście metod badawczych. To na tym polu socjologia wizualna zaciągnęła wobec antropologii wizualnej największy dług. To również na tym polu najtrudniej odróżnić od siebie obie dyscypliny (więcej na temat zob. Olechnicki 2003a, s. 29).

Z konieczności krótką historię wykorzystania fotografii w metodach antropologicznych trzeba rozpocząć od pionierskich badań Margaret Mead i Gregory'ego Batesona, którzy wykorzystywali film i fotografię $\mathrm{w}$ dokumentacji zwyczajów mieszkańców Bali. Datę publikacji wyników (Bateson, Mead 1942) można uznać za moment, w którym w polu profesjonalnych badań społecznych zakiełkowała idea fotografii jako przedłużenia metody obserwacji. Co ważne, Mead traktowała materiały wizualne również jako formę popularyzacji antropologii, zarówno wśród studentów, jak i świata pozaakademickiego (Henny 1986, s. 15-16).

Podobnie istotne są badania Johna Colliera (m.in. 1957; 1979a, 1979b; Collier, Collier 1986) - bodaj pierwszego autora, który podjął systematyczny namysł na technikami wizualnymi w naukach społecznych i który już od $1957 \mathrm{r}$. podejmował pierwsze próby wykorzystania wywiadu fotograficznego. Warto też wspomnieć o badaniach Adaira i Wortha (1972), którzy jako pierwsi wykorzystali technikę autofotografii (rozdali Indianom Navaho kamery, przy okazji 
badań nad tym, jak postrzegają sami siebie i rzeczywistość społeczną, która zamieszkuja). Dodajmy do tego pierwsze filmy etnograficzne i antropologiczne. O wielkości antropologicznego wkładu w socjologię wizualną niech świadczy choćby tyle, że wszystkie wspomniane techniki składają się na trzon metod używanych dzisiaj przez socjologię wizualną.

Kolejną inspiracją była sama fotografia. Zacznijmy nietypowo — od teoretyków. W wielkim skrócie: mieliśmy w Polsce wielu „socjologizujących” teoretyków i krytyków fotografii, którzy wnieśli ogromny wkład w sposób rozumienia fotografii przez socjologię. Teoretykom takim jak Urszula Czartoryska (zob. m.in. 1965; 1981a; 1981b; 2007), Jerzy Busza (zob. m.in. 1981a, 1981b; 1990), Juliusz Garztecki (zob. m.in. 1977; 1981), Alferd Ligocki (zob. m.in. 1979; 1987) czy socjolog Sławomir Magala (zob. m.in. 1978; 1979; 1982; 2000) polska socjologia wizualna zawdzięcza nie tylko pierwsze istotne przekłady, ale przede wszystkim teksty krytyczne (publikowane głównie na łamach „Fotografii”), które dokonały istotnego przesunięcia w sposobie analiz fotografii z kanonów czysto estetycznych (albo z perspektywy jakiejś istoty medium) w kierunku zdecydowanie bardziej społecznym, kładąc grunt pod socjologiczne myślenie o fotografii jako praktyce społecznej na długo przed pojawieniem się terminu „socjologia wizualna” 6 .

Jeżeli chodzi o wkład samych fotografów, to wystarczy kilka najbardziej znanych nazwisk. Społeczeństwo stało się przedmiotem fotoreportaży, a czasem nawet całych archiwów, u takich fotografów, jak Jacob Riis, Lewis Hine — socjolog z wykształcenia, Eugéne Atget, Dorothea Lange czy August Sander, a w Polsce na przykład Benedykt Jerzy Dorys, Władysław Sławny, Jerzy Kosidowski, czy wreszcie niesamowita Zofia Rydet i jej fenomenalny Zapis socjologiczny (o „socjologiczności” tego ostatniego zob. np. Panek-Sarnowska 2005). Niektórzy z nich świadomie uczestniczyli w konkretnych projektach naprawy społeczeństwa; inni poświęcili się tworzeniu prawie pośmiertnych portretów zmieniającego się społeczeństwa i kultury w dobie modernizacji. Jeszcze inni, zdecydowanie mniej zaangażowani, po prostu interesowali się życiem codziennym i poszukiwaniami najlepszej formy opowiadania o nim.

Socjolog może więc użyć w swoich analizach zdjęć dokumentalnych wykonanych przez profesjonalnych fotografów, może też brać przykład z pewnych podejść fotograficznego dokumentowania, próbując fotografować samemu, w celach badawczych (fotografowie, inaczej niż teoretycy fotografii, inspirowali

6 Trzeba zaznaczyć, że rozwój i profesjonalizacja socjologii/antropologii wizualnej bynajmniej nie stłumiły podobnych inicjatyw. Warto w tym kontekście wspomnieć między innymi dorobek Tomasza Ferenca, który w swojej pracy redaktorskiej (zob. Ferenc 2006b; Ferenc, Makowski 2005; Ferenc, Studzińska 2007; Ferenc, Kowalewicz 2009) stara się przerzucać mosty między akademicką nauką społeczną a krytykami i teoretykami fotografii; książkę Sławomira Sikory (2004); oraz prace Marianny Michałowskiej, dotyczące między innymi filozofii reprezentacji, fotografii dokumentalnej, kulturowego statusu medium oraz codziennych użytków, w które jest ono wplecione (zob. m.in.: 2004; 2005; 2007; 2008). 
zatem nie tyle przedmiot badań, co metody ich przeprowadzania, ewentualnie dostarczali materiał badawczy). Czy jednak istnieje coś takiego jak fotografia socjologiczna? Czym różniłaby się ona od fotografii społecznej? Co wnosi to do rozważań nad historią socjologii wizualnej?

W polskiej literaturze wątek ten przewijał się w tekstach krytycznych już w latach siedemdziesiątych. Przełomem był jednak rok 1980, kiedy to w Bielsku-Białej zorganizowano wystawę poświęconą „, fotografii socjologicznej”, połączoną z sympozjum na ten sam temat. W 1981 r. socjolog Andrzej Ziemilski opublikował na łamach „Fotografii” artykuł Fotografia a warsztat socjologa, w którym, na długo przed Piotrem Sztompką, określił rolę zdjęć w socjologii, widząc w nich przede wszystkim utrwalanie obserwacji. W 1987 r. Alfred Ligocki wydał swoją książkę pod frapujących tytułem Czy istnieje fotografia socjologiczna?. Co istotne, problem, który był w niej rozważany, dotyczył już nie tyle funkcji zdjęcia jako zapisu obserwacji, który może inspirować hipotezy badawcze (co już wówczas wydawało się oczywiste), ale jego analitycznych możliwości, które wiązałyby się między innymi z możliwością weryfikowania hipotez (Ligocki 1987, s. 8-9).

Przy tak postawionym pytaniu Ligocki nie ma wątpliwości - „poznawcza funkcja fotografii w odniesieniu do społeczeństwa znaczenie bliższa jest sztuce niż nauce. I dlatego pozwalam sobie stwierdzić, że nie ma fotografii socjologicznej, podobnie jak nie ma socjologicznego malarstwa czy poezji" (Ligocki 1987, s. 127). Jeśli mamy na uwadze ówczesne rozumienie socjologii (a także wiarę Ligockiego w obiektywność medium), to odpowiedź ta nie zaskakuje. Gdy myślimy dzisiejszymi kategoriami badań społecznych — być może nie jest ona już tak oczywista. Na przykład Jon Wagner (2004, s. 1503), bez spierania się o nazwę, różnic między fotografią wykonaną do celów badawczych a dokumentalną fotografią społeczną dopatruje się już nie tyle w poznawczych i analitycznych możliwościach zależnych od sposobu wykonywania zdjęcia, ile w motywacjach, grupie docelowej i w sposobie ustrukturyzowania procesu badawczego, w który wplecione jest takie fotografowanie.

Jak pamiętamy, Grady (2007) wskazał na dwa główne typy źródeł socjologii wizualnej; dotychczas mowa była jedynie o pierwszym z nich (metodach). Drugim było charakterystyczne dla zachodniej kultury zainteresowanie reprezentacjami wizualnymi ${ }^{7}$. Impuls ponadto istotny dlatego, że jego przypomnienie pozwala wyłuskać rodowód intelektualny kolejnych narzędzi używanych w socjologii wizualnej (tym razem chodzi o krytyczną analizę reprezentacji) oraz samą socjologię wizualną na planie semiologii i krytycznych teorii dyskursu, czerpiących pełnymi garściami głównie z myśli poststrukturalistycznej (zob. np. Rose 2001).

7 Wydaje się, iż Grady’emu umyka jeszcze jedno istotne źródło socjologii wizualnej — zainteresowanie wzrokowymi formami doświadczania kultury. Piszemy o tym w dalszej części tekstu. 
Badacze społeczni na dobre zaczęli interesować się obrazami jako elementami życia społecznego na początku XX wieku, w okresie wzrostu znaczenia mediów masowych, które zaczęto rozpatrywać jako mechanizmy kreujące zbiorową wyobraźnię - najpierw podług zasad propagandy rozumianej jako zaplecze dla rodzących się totalitaryzmów, potem wedle reguł przemysłu kulturowego. Zainteresowanie mediami masowymi, którego początków można upatrywać w myśleniu marksistowskim i szkole frankfurckiej z lat trzydziestych sprowokowało rodzaj refleksji, który - opisując historie kontaktów socjologii z reprezentacjami - zwykło się określać mianem „paradygmatu krytycznego” (Chaplin 1994).

Jednak mimo że krytyczne analizy przedstawień obecne były w naukach społecznych od dawna (zob. chociażby: Benjamin 1936; Bloch 1935 czy Kracauer 1947), dopiero w latach siedemdziesiątych zaczęto konsekwentnie stosować takie podejście do społecznej krytyki filmu i fotografii (trochę zapominając przy tym o wspomnianych teoretykach, inspiracje czerpiąc za to bardziej z Foucaulta, Althussera i badań Stuarta Halla) i, podobnie jak w latach wcześniejszych, raczej poza instytucjonalnym kontekstem samej socjologii. Ogromne znaczenie miały tu również teoretyczne pomysły Rolanda Barthesa, który argumentował, że teksty kultury lepiej oglądać jako systemy znaków, łączące się ze sobą w określone konstelacje, niż jako odniesienie do jakiegoś świata zewnętrznego.

Od tego momentu mechaniczna reprezentacja zaczyna być poddawana rozmaitym krytycznym śledztwom - jako w taki czy inny sposób reprodukująca nierówności. Analiza klasowa przestaje być przy tym z czasem jedyną, która odkrywa nierówne dystrybucje władzy w kulturze i powoli ustępuje na rzecz analiz spod znaku gender i ethnic (Chaplin 1994). Mniej więcej od tego czasu zaczął również zanikać badawczy podział na sztukę i nie-sztukę. Badaczy zainspirowanych wspomnianymi pomysłami teoretycznymi interesują, przynajmniej w tym samym stopniu, co muzealny „kanon” historii sztuki, obrazy komunikowane $\mathrm{w}$ mediach, czyli takie, które można posądzić o istotny wpływ na wyobraźnię społeczną - rozpoczynają się analizy reklam. Johna Tagga nie interesuje już fotografia-jako-sztuka i fotografia-jako-historia-medium; interesuje go fotografia jako wypadkowa historii i relacji władzy (Chaplin 1994, s. 82).

Victor Burgin mówi o wielojęzyczności fotografii i krytykuje obowiązujący model opowiadania jej historii przez pryzmat wielkich nazwisk; Jo Spence, podobnie jak Tagg, podejmuje wątki polityczne i ideologiczne, ale optuje za praktycznym wykorzystaniem tej wiedzy w próbie budzenia krytycznego spojrzenia u odbiorców; Vilém Flusser rozważa wpływ, jaki apparatus ma na uprzedmiotowienie jednostki/programowalność jej doświadczenia; Frank Webster kładzie za to nacisk na związki fotografii ze stosunkami ekonomicznymi (zob. Ferenc 2004b, s. 187-203). Wszyscy wymienieni sprzeciwiają się teorii fotografii budowanej na założeniu o ontologicznym realizmie zdjęć-świadectw (Ferenc 2004b, s. 173), widząc w nich raczej ideologicznie wytwarzany „efekt realno- 
ści" (określenie Barthesa, za: Bal 2006, s. 301). To dlatego zaczynamy pytać nie tylko o obrazy, ale przede wszystkim o systemy kontroli, praktyki i instytucje dyskursywne, które nadają im znaczenie. Mniej więcej w podobnym kontekście można umieścić również inspirowane teorią Lacana refleksje o popędzie skopicznym, autoobserwacji, voyeuryzmie, spojrzeniu itd., mające odniesienie również do analiz obrazów (zob. Rose 2001).

Podczas gdy paradygmat krytyczny zwraca uwagę na fakt, że nasze czynności i znaczenia, które im przypisujemy, są przesiąknięte ideologicznie, paradygmat empiryczny — zorientowany przede wszystkim na życie codzienne, traktowane jako rodzaj udyskursowionej, ale przede wszystkim wcielonej wiedzy, inspirowany interakcjonizmem, etnometodologią i socjologią fenomenologiczną traktuje owe czynności/znaczenia jako zależne przede wszystkim od kontekstu, w którym przebiegają, zwracając przy tym uwagę, że właśnie na tym planie należy je analizować (Chaplin 1994, s. 159).

Podejście empiryczne, inaczej niż krytyczne, ugruntowane jest zatem w pracy terenowej, w obserwacjach i wywiadach ze „zwykłymi ludźmi”, traktowanymi jako uczestnicy i współtwórcy kultury, którzy jako tacy mogą dostarczyć istotnych informacji o tym, w jaki sposób uwzględniają/używają/rozumieją różne typy danych wizualnych $\mathrm{w}$ swoich codziennych interakcjach. $Z$ tych powodów paradygmat empiryczny wydaje się też genetycznie bliższy socjologii niż jakimkolwiek innym dyscyplinom. Z punktu widzenia przedmiotu socjologii wizualnej równie istotny, jak możliwość odwołania się do tradycji dyscypliny, wydaje się jednak fakt, że bez badania tego, co odbiorcy robią z obrazami, nie może ona odpowiedzieć na wiele ważnych dla niej pytań. Nie bardzo możemy pytać na przykład o strategie komunikacyjne, w które wplecione są obrazy, ani o ich „kariery” (określenie Grady'ego ${ }^{8}$ ), które pozwoliłyby określić ich społeczne (kulturowe) znaczenie.

Podsumujmy dotychczasowe rozważania. Powstanie i obserwowalny wzrost zainteresowania socjologią wizualną można wiązać, po pierwsze, ze wzrostem roli kultury wizualnej w życiu społeczno-kulturowym; po drugie, z szerszą tendencją obserwowaną w socjologii od przełomu lat sześćdziesiątych i siedemdziesiątych, która wiąże się ze spadkiem popularności „socjologii systemowej”, a w konsekwencji, po trzecie, także ze wzrostem zaufania dla metod jakościowych (wydają się one lepiej dostosowane do nowych pytań). Wszystko to skutkuje intelektualnym „klimatem”, który coraz bardziej sprzyja powszechnemu zainteresowaniu obrazem $\mathrm{w}$ naukach społecznych. Ewoluuje również pole socjologii, w obrębie którego socjologia wizualna staje się coraz bardziej do pomyślenia.

\footnotetext{
8 John Grady (2007, s. 64) słusznie zwraca uwagę, że obrazy nie tylko opowiadają jakąś historię, mając przy tym swój ukryty tekst ideologiczny (politic), ale także — no właśnie — swoje „kariery”: podróżują od jednego kontekstu do drugiego, radykalnie zmieniając po drodze znaczenie, które jest im przypisywane.
} 
Kłopot jednak w tym, że da się ją pomyśleć przynajmniej dwojako, co samo w sobie trudno traktować jako słabość socjologii wizualnej, ale co stwarza problem podczas opisywania jej obszaru. Ową „podwójność” dobrze zresztą widać nie tylko w inspiracjach, ale również w tym krótkim podsumowaniu. Gdyby je bowiem trochę rozpisać, okazałoby się, że ów klimat, o którym mowa, związany jest dwiema, dosyć jednak odrębnymi grupami czynników. Dlatego dalej łatwiej będzie określić rozwój polskiej socjologii wizualnej sięgając po dwa sposoby jej rozumienia: w zakresie węższym, który koncentruje się na metodach/technikach badawczych, jest wspólny dla wszystkich badaczy oraz stanowi jej rdzeń, oraz szerszym, stanowiącym akces do interdyscyplinarnego projektu refleksji nad kulturą wizualną. Innymi słowy, idąc trochę na skróty, socjologia wizualna to tyle, co wizualne techniki badawcze do wykorzystania w socjologii oraz socjologia kultury wizualnej. Co istotne, $\mathrm{w}$ procesie badawczym jedno wcale nie musi iść $w$ parze $z$ drugim (i w rzeczywistości nie zawsze chadza).

\section{SKRZYNKA NARZĘDZIOWA}

Socjologia wizualna $\mathrm{w}$ wąskim rozumieniu odnosiłaby się zatem do zastosowań „technicznych" i metodologicznych, zatrudniając reprezentacje wizualne (głównie fotografię i film, ale też rysunki, mapy, wizualizacje komputerowe itd.) jako narzędzia do analiz społeczeństwa i kultury (Grady 2007, s. 63). Co ważne, czyniłaby to wszystko bez względu na to, jakiego konkretnego tematu i przedmiotu dotyczą takie badania oraz jaka jest $\mathrm{w}$ nich rola (status) obrazu. Opierałaby się na założeniu o „pragmatycznym realizmie”, czyli podejściu, które nie opowiada się na stałe za stanowiskiem krytycznym czy mimetycznym i które bardziej niż rozważaniem ontologicznego s tat u su obrazu (co nie w każdym przypadku jest niezbędne) zainteresowane jest możliwościami wykorzystania go w terenie - w konkretnych projektach badawczych (Knowles, Sweetman 2004, s. 6), albo w dydaktyce - w procesie komunikowania wyników badań lub wizualizacji teorii.

Taka „pragmatyczna” socjologia wizualna na wstępie (najczęściej) odrzuca przy tym zarówno naiwną wiarę $\mathrm{w}$ obiektywizm fotografii, wyznawaną przez pierwszych antropologów, jak i przekonanie o tym, że obrazy są wyłącznie „nośnikiem politycznej tyranii” (określenie Williama J. T. Mitchella - 2006, s. 288), które towarzyszyło pierwszym neomarksistowskim krytykom fotografii; zakłada po prostu, że w przypadku niektórych obrazów i niektórych sposobów ich wykorzystania warto uznać reprezentacyjną sprawność obrazu (Knowles, Sweetman 2004, s. 6). Tak rozumiany pragmatyczny realizm stanowi podstawę czterech kluczowych sposobów wykorzystywania obrazu w socjologii: służy do generowania danych, komunikowania wyników, ilustracji wywodu oraz wizualizacji teorii.

Ostatnie trzy z wymienionych użyć trudno przy tym uznać za charakterystyczne jedynie dla socjologii wizualnej: ilustracje, prezentacje, wykresy, tabele, 
mapy i inne grafiki wzmagające zaangażowane czytanie ułatwiają odbiorcom przyswojenie przekazywanych treści daleko poza jej obszarem i używane były w ten sposób na długo przed uformowaniem się jej zrębów. W tym sensie ich wykorzystanie jest oczywiste, i to w takim stopniu, że nawet sami socjologowie wizualni przestali zwracać na nie uwagę; zupełnie zresztą niesłusznie i ze sporą stratą dla własnego obszaru studiów - o czym piszą niektórzy teoretycy (zob. np. Grady 1998, 2006, 2009; Pauwels 2000; Wagner 2006).

Zdecydowanie bardziej charakterystyczne są $\mathrm{w}$ tym kontekście filmy socjologiczne oraz fotoeseje. Jeżeli chodzi o te pierwsze, to warto przywołać poznańską Pracownię Socjologii Wizualnej i jej kierownika - Jerzego Kaczmarka (zob. np. Kaczmarek 2008) ${ }^{9}$. Pierwsze filmy powstały tam już w latach dziewięćdziesiątych, na przykład Jak się święci 1 Maja. Ciągle powstają też kolejne - po 2000 r. między innymi Przystanek, wart wspomnienia jako pierwszy film socjologiczny, dołączony do publikacji książkowej (Krajewski 2007).

Co zaś tyczy się fotoesejów to, znowu pomijając oczywiste korzenie w fotoreportażach czy formalnych eksperymentach w stylu Another Way of Telling (Berger, Mohr 1995), powiedzmy tylko tyle, że podobnie jak filmy socjologiczne od zwykłych zapisów rejestracji różnią się tym, że stanowią rodzaj narracji, która przekształca obrazy z zapisu $\mathrm{w}$ analizę społeczeństwa; podążają za wcześniej postawionymi pytaniami i opierając się na przyjętych założeniach teoretycznych przypisują obrazowi i tekstowi równe prawa; poprzez ich połączenie wytwarzają rodzaj „hipertekstu” (jak określa fotoesej Rafał Drozdowski; 2004). W jakim stopniu przekonujący jest sam format i jego socjologiczne opracowanie, $\mathrm{w}$ polskim wydaniu można się przekonać na przykład w książce Obrazy w działaniu (Olechnicki 2003b) albo Kadrowanie rzeczywistości (Kaczmarek 2004).

Filmy i fotoeseje mogą pełnić, poza poznawczą, również funkcję popularyzatorską - przybliżając $\mathrm{w}$ przystępny sposób tematy i problemy socjologiczne. Tak też są najczęściej wykorzystywane: w przerwach konferencji, na dniach otwartych albo na festiwalach naukowych. Dotychczas nie doczekaliśmy się w Polsce bardziej systematycznych przedsięwzięć. Za granicą funkcjonują natomiast specjalistyczne czasopisma. Warto tu przywołać „Visual Studies” (publikowane w „podwójnej” wersji - zarówno drukowanej, jak i multimedialnej, załączonej na płycie CD, która zawiera zarówno tekst, jak i stanowiące jego nieodłączny element zdjęcia), a także wydawane przez Amerykańskie Towarzystwo Socjologiczne czasopismo „Contexts”, które na pierwszym pla-

${ }^{9}$ Można by oczywiście szukać głębiej i przywołać np. filmy Kazimierza Karabasza, ale gdyby odciąć wątek inspiracji i archeologii samego terminu „film socjologiczny”, skupiając się tylko na tych, które kręcone były na socjologii, przez socjologów i urefleksyjniane w kierunku możliwości bycia socjologią-jako-narracją-naukową (czyli pójść nie tropem interpretacyjnym, lecz raczej instytucjonalnym), to wtedy za pierwsze takie filmy trzeba by uznać te, które zaczęły powstawać właśnie w Pracowni Socjologii Wizualnej. 
nie stawia informacje i narracje wizualne, traktowane jako rodzaj wypowiedzi naukowej ${ }^{10}$.

Kolejnym metodologicznym zastosowaniem socjologii wizualnej, a tak naprawdę dopiero pierwszym, który stanowi o jej naukowej swojskości, są różnego rodzaju wizualne metody badawcze, między innymi: wywiad fotograficzny, rejestracja obserwacji, wizualna metoda biograficzna (analiza albumów fotograficznych) oraz autofotografia i refotografia (fotografia powtórna - technika polegająca na fotografowaniu jakiegoś obiektu w określonych odstępach czasowych, przy zachowaniu możliwie tych samych zasad kadrowania; użyteczna na przykład w badaniach nad zmianą społeczna). Warto przy tym zaznaczyć, że obrazy wykorzystywane $\mathrm{w}$ wymienionych technikach mogą pochodzić $z$ trzech źródeł: mogą być zastane (np. prasowe lub reklamowe), wykonane przez badacza lub wykonane przez badanego. Ich metodologiczne wykorzystanie zaś może być $z$ grubsza dwojakiego rodzaju: mogą służyć jako narzędzie i jako surowiec.

Pierwsze korzysta z obrazów w sposób instrumentalny, bazując na ich projekcyjnych/protetycznych właściwościach, posługując się nimi do generowania danych innego typu (najczęściej wypowiedzi słownych). Najlepiej widać to na przykładzie wywiadu fotograficznego — zdjęcie staje się tu pretekstem do uzyskiwania od respondentów informacji, które w tradycyjnych formach wywiadu byłyby trudne lub wręcz niemożliwe do wydobycia (stąd funkcja projekcyjna). Wraz ze zdjęciami badacz może wnieść do wywiadu kawałki rzeczywistości, której z jakichś powodów nie ma: momenty „nie teraz”, wydarzenia „nie tutaj”, aktorów „nie ma ich” (Törrönen 2002, s. 348, por. Crilly, Blackwell, Clarkson 2006). Działa to też w drugą stronę - to badany może posiadać zdjęcia przedmiotów, obrzędów, wydarzeń, ludzi i miejsc, które interesują badacza, a które nie są mu dostępne (stąd funkcja protetyczna).

Sam wywiad fotograficzny może być przy tym wykorzystywany przy okazji różnego rodzaju problemów badawczych, niekoniecznie (a nawet rzadko) związanych $z$ samą kulturą wizualną. $Z$ tego też powodu polska historia jego wykorzystywania sięga dalej niż opisywane wcześniej kilka lat instytucjonalizowania się socjologii wizualnej; wspominaliśmy na wstępie, że pierwsze tego typu badania prowadził już w połowie lat osiemdziesiątych Krzysztof Koseła, który jako pierwszy polski socjolog podjął również teoretyczny namysł nad specyfiką (wadami i zaletami) takiej techniki badawczej (zob. Koseła 1989; 1990).

Drugie wykorzystanie polega na posługiwaniu się obrazem jako surowcem, wydobywanym na różnych etapach procesu badawczego, będącym punktem

10 Douglas Harper twierdzi, iż tego typu przedsięwzięcia mają na celu doprowadzenie do traktowania zdjęć jako pełnoprawnych danych wizualnych. Wspomina przy tym o problemie wiarygodności fotografii jako medium (Harper 2005); podobne uwagi pojawiają się dość często w publikacjach socjologów wizualnych, którzy porównują tę kwestię z problemem trafności w badaniach statystycznych (Henny 1986, s. 52-53). 
wyjścia do interpretacji. Można tu mówić przede wszystkim o autofotografii oraz obserwacji (i jej fotograficznej lub filmowej rejestracji). Technika autofotografii polega na zadaniu badanym pytań (bardzo ogólnych lub szczegółowych) i poproszeniu o odpowiedź na nie, jednak nie w formie werbalnej, lecz za pośrednictwem samodzielnie wykonanych zdjęć. Dla badacza istotne jest zarówno to, co obraz pokazuje, jak i to, w jakim kontekście i w jaki sposób zdjęcie zostało wykonane, jakie elementy zostały z niego wyeliminowane itd. Najistotniejszym elementem jest w tym przypadku nie tyle obiektywność zdjęcia, ile subiektywne podejście osoby je wykonującej, pozwalające dotrzeć do sposobu, w jaki badany ogląda i wartościuje świat. Tak wykorzystano fotografię na przykład w poznańskich badaniach prowadzonych w latach 2005-2007 w ramach grantu dotyczącego pojęcia wyobraźni społecznej (Drozdowski, Krajewski 2008), jak również we wspominanych już badaniach Koseły $(1989,1990)$ i Kaczmarka $(2002,2004)$.

Rejestracja obserwacji wychodzi natomiast $z$ odmiennych założeń. W tym przypadku osobą wykonującą zdjęcie/film jest w zdecydowanej większości przypadków sam badacz, który wierzy w obiektywną naturę wytwarzanych obrazów (a przynajmniej w to, że odpowiednio wykonane mogą być źródłem wiarygodnych informacji). Zdjęcie lub film są więc tutaj rejestracją te g o-co-n a ocz ne, rodzajem notatnika terenowego, odzwierciedleniem i uwiecznieniem tych wszystkich elementów, które widzi/widziało ludzkie oko, a także tych, które przeoczyło. Dzięki temu istnieje możliwość analizy danych wizualnych (naocznych) nie tylko podczas ich obserwacji, ale również później, nierzadko w bardziej komfortowych warunkach — gdy zapisane nagranie można zatrzymać, zwalniać, przewijać, powiększać - widzieć lepiej. W Polsce dobrego przykładu takiego empirycznego podejścia dostarczył Krzysztof Konecki (2005a), który używał $\mathrm{w}$ ten sposób fotografii i filmu między innymi w swoich badaniach nad wymianą gestów między ludźmi i zwierzętami, łącząc w nich techniki wizualne z metodologią teorii ugruntowanej (zob. też Konecki 2005b; 2008).

Mówiąc o obserwacji, warto też wspomnieć o różnego rodzaju otwartych bazach danych wizualnych, których rozwój postulował kilka lat temu Rafał Drozdowski (2006) i które mogą stanowić materiał empiryczny do dalszych analiz; również tych prowadzonych z perspektywy czasu, kiedy to archiwa i złożone w nich zdjęcia stanowią jedyny sposób dotarcia do etnografii rzeczywistości, której już nie ma albo która jest już dużo mniej widoczna niż kiedyś. Pozwala to na przykład na badanie zmian w społeczeństwie. $Z$ podobnych baz korzystał Marian Golka, który w swoich badaniach nad środowiskiem wizualnym wielkiego miasta pracował na zdjęciach archiwalnych zdeponowanych w zbiorach miejskich i robił to już na początku lat osiemdziesiątych, a więc na długo przed wynalezieniem określenia „socjologia wizualna” ${ }^{11}$.

$11 \mathrm{~W}$ rozmowie Marian Golka wspominał, że pomysł takiego badania i takiego wykorzystywania zdjęć wziął się z jego zainteresowań kulturą plastyczną i miastem, które dzielił ze swoim promo- 
Przykładem współcześnie stosowanego podejścia do baz wizualnych polegającego nie tyle na korzystaniu ze zdjęć zastanych, ile na tworzeniu również własnych obrazów - jest ogólnopolski projekt Niewidzialne Miasto (www.niewidzialnemiasto.pl), którego rezultaty są zamieszczane i komentowane na publicznej i regularnie aktualizowanej stronie internetowej i który był pomyślany między innymi jako monitoring estetyk, które współcześnie stają się coraz rzadsze. Strona www stanowi rdzeń pierwszej części projektu. Obecnie trwają przygotowania do etapu drugiego - projektu badawczego, którego celem będzie socjologiczne opracowanie zebranego materiału i włączenie wyników w badanie poświęcone fenomenowi urbanizmu codziennego.

Pozostając jeszcze na chwilę przy obserwacji, należy stanowczo przypomnieć, że przekonanie o tym, iż socjolog interesujący się wizualnością to socjolog, który zajmuje się tylko analizą zdjęć i filmów, jest w dużym stopniu uproszczeniem, który zresztą znacznie ogranicza zakres tematyczny badań (Emmison, Smith 2000). Tak rozumiana socjologia wizualna może się uczynić spadkobierczynią tradycji znowu o wiele dłuższej niż sam termin. Wystarczy wspomnieć badania nad stylami życia, które na najbardziej podstawowym poziomie również polegają na założeniu, że obserwowalny wymiar zachowań jednostek oraz środowiska materialnego, w jakim one operują, stanowi wiarygodne źródło wskaźników o postawach, do których stara się dotrzeć badacz.

Warto zatem przypomnieć za wspomnianymi wcześniej autorami, że socjolog, którego interesuje wizualny wymiar rzeczywistości społecznej, zajmować się może nie tylko obrazami dwuwymiarowymi (zdjęcia, filmy, mapy itd.), ale też trójwymiarowymi (przedmioty, ciało itd.), a także interakcjami (na wzór Goffmanowski). Jak bowiem słusznie zauważa Piotr Sztompka (2006) — zwróćmy uwagę, że na tym etapie rozważań zabrzmi to zdecydowanie mniej opresyjnie niż wtedy, kiedy przywoływaliśmy podobny pogląd Andrzeja Ziemilskiego (1981) - socjologii wizualnej w znaczeniu metod jest zdecydowanie bliżej do obserwacji niż do strukturalistycznej analizy obrazu (zob. też Olechnicki 2000). I to już nie ze względu na jakieś jarzmo pozytywizmu (trudno tak określić na przykład interakcjonizm czy teorię dramaturgiczną), a prostu $z$ powodu innych tradycji teoretycznych i badawczych.

torem - Aleksandrem Wallisem. Nie odczuwał wówczas potrzeby wynajdywania nowej nazwy swojej praktyce, która wydawała się naturalna i dobrze zakorzeniona w socjologicznej tradycji badawczej. Jeżeli korzystał z jakichś pomysłów teoretycznych, to były to raczej nawiązania do badań Lyncha i Gibsona nad percepcją niż do rozwiązań proponowanych na przykład przez semiologię. Wspominamy historię tych badań, ponieważ są one w pewnym sensie symptomatyczne dla ówczesnego sposobu myślenia o zdjęciach/obrazach w socjologii. Zresztą nie tylko ówczesnego charakteryzuje on do dzisiaj socjologów wykorzystujących obrazy w sposób, który określiliśmy wyżej jako pragmatyczny. 


\section{SOCJOLOGIA KULTURY WIZUALNEJ}

Kiedy Tomasz Ferenc formułował program swojej socjologii fotografii, przywoływał, za Douglasem Harperem, dwa podejścia badawcze, które - z grubsza — odpowiadają węższemu i szerszemu rozumieniu socjologii wizualnej. $Z$ jednej strony, mamy „orientację na sprzęt” — wykorzystanie aparatu/kamery jako narzędzia w pracy badawczej i dydaktycznej, z drugiej zaś „orientację na obraz”, czyli „zainteresowanie społecznymi funkcjami obrazu, mass mediami, semiotyką" (Ferenc 2001, s. 86; por. Harper 1986, s. 48). O ile pierwsza z tych orientacji odpowiada metodom wykorzystywanym w socjologii wizualnej bez względu na temat badań, o tyle druga kładzie akcent na charakterystyczny przedmiot refleksji. O pierwszej była mowa wyżej, o drugiej pomówimy teraz.

O przedmiocie socjologii wizualnej zresztą też już trochę mówiliśmy. Przy okazji rekonstruowania korzeni subdyscypliny przywoływaliśmy teksty autorów niemieckich, wskazywaliśmy również na przedefiniowanie statusu zdjęć dokonanego głównie w kręgu brytyjskich teoretyków fotografii, inspirowanych filozofią francuską i badaniami Brytyjskiej Szkoły Badań Kulturowych. Zwłaszcza ten drugi kontekst wydaje się istotny dla sposobu, w jaki socjologia wizualna patrzy dziś na obrazy — szukając znaczenia fotografii nie w jakiejś istocie zapisu, ale na zewnątrz samego zdjęcia. Skoro fotografia nie ma swojej tożsamości, czyli ontologiczne rozważania jej „natury” do niczego konkretnego w socjologii nie prowadza, to należy się skupić na konkretnych kontekstach dyskursywnych, które nadają jej znaczenie (Ferenc 2006a, s. 80).

Co istotne, to właśnie na wzór osiągnięć brytyjskich teoretyków fotografii, uzupełnionych o refleksję Bourdieu (1990) i Flussera (2004), Tomasz Ferenc wyznacza zakres i zadania drugiego członu proponowanej przez siebie socjologii fotografii, którą widzi jako ukonkretnienie socjologii obrazu; w ten sposób zdjęcie staje się nie tylko narzędziem, ilustracją czy oknem, ale również lustrem społeczeństwa. Wskaźnikiem instytucji, które się nań składają i w którym przeglądają się na co dzień jednostki. Tak pojmowane zdjęcie stanowi dla socjologa skarbnicę informacji i punkt wyjścia do „badania społeczeństwa funkcjonującego w dobie audiowizualności" (Ferenc 2001, s. 83) ${ }^{12}$.

12 „Socjologia fotografii koncentruje się na badaniu samego fenomenu społecznego jakim jest fotografia, ogniskując swoje zainteresowania na praktykach społecznych związanych $z$ fotografią, recepcją zdjęć oraz instytucjach fotograficznych. Badanie praktyk dotyczyłoby sposobów wykorzystywania technik fotograficznych, tego jakie zwyczaje się z tym wiążą, na przykład zasad wykonywania zdjęć pamiątkowych czy konstruowania albumów rodzinnych. Problem recepcji jest jednym z kluczowych, „czytanie” zdjęć, poznanie mechanizmów ich interpretacji stanowi ważne zadanie dla socjologii fotografii. I wreszcie problematyka związana $z$ instytucjami otwiera przed badaczem cały szereg zagadnień. Po pierwsze galerie jako instytucje promujące pewien rodzaj fotografii a co za tym idzie stwarzające kanon fotografii oficjalnie akceptowanej. Po drugie szkoły fotograficzne, kształcące przyszłych fotografów i ich rola w upowszechnianiu tego kanonu. Instytucje to także zakłady fotograficzne i wielkie monopolistyczne firmy, kontrolujące rynek produkcji i usług fotograficznych" (Ferenc 2001, s. 86-87). 
Dopiero tak szerokie ujęcie tematu pozwala, zdaniem Ferenca (2001, s. 96), zrozumieć miejsce i znaczenie fotografii w życiu społecznym; taki jest też cel proponowanej przez niego subdyscypliny. Dobrze odpowiadają takiemu zamysłowi również pierwsze polskie próby realizacji, w których teoretyzuje się obrazy w konkretnym kontekście dyskursywnym, traktuje się je jako kolejny wymiar zjawisk społecznych, zarówno tych badanych w socjologii od dawna, jak i tych stosunkowo nowych ${ }^{13}$. Warto jednak zwrócić uwagę, że nawet tak szeroko zakreślony program socjologii fotografii zawęża obszar rozważań, które mogłyby się stać udziałem socjologa wizualnego. Utrudnia zresztą również zrozumienie fotografii traktowanej jako praktyka społeczna.

Wprawdzie Ferenc pisze, że socjologia fotografii stanowi zaledwie fragment szerszego programu socjologii obrazu, która zajmowałaby się nie tylko społecznym życiem obrazów dwuwymiarowych, ale w ogóle wizualnym wymiarem fenomenów kulturowych - interakcjami, rytuałami, materialnością itd.; cytuje i utożsamia się ze zdaniem Olechnickiego, że „obrazy” w nazwach socjologii i antropologii obrazu niewiele mają wspólnego z „obrazkami” (zdjęciami, malowidłami, telewizja), ale odnoszą się do wszystkiego „co widać” (Olechnicki 1999, s. 40, por. Ferenc 2001, s. 83). Mimo to - podobnie jak Olechnicki umieszcza fotografię $\mathrm{w}$ centrum nie tylko własnych rozważań, ale też $\mathrm{w}$ centrum współczesnej kultury wizualnej (Ferenc 2001, s. 97), narażając się w ten sposób na błędy redukcji kultury wizualnej do „społecznej konstrukcji obszaru wizualnego”, „zwrotu piktorialnego”, „technicznej nowoczesności”, „mediów wizualnych" i „władzy” (określenia Mitchella; 2006) ${ }^{14}$.

To zatem nie przypadek (ani regionalna tradycja), że mimo pełnego utożsamienia się z programem socjologii i antropologii obrazu optujemy tu raczej za terminem „socjologia wizualna". Najlepiej można wytłumaczyć to wpływem, który na rozumienie subdyscypliny w kręgach związanych z poznańską Pracownią wywarła tradycja intelektualna refleksji nad kulturą wizualną — bardziej niż tylko nad kulturą obrazu. W szczególności zaś sposób, w jaki pisze o niej

\footnotetext{
13 Zob. np. konstruowanie rzeczywistości - Fotografia i telenowela — dwa przykłady konstruowania rzeczywistości (Ferenc, Sułkowski 2004); reklama - Medialna kultura moratorium. Nowoczesność i tradycja w polskich reklamach telewizyjnych (Krajewski 1999); miasto - Wizualność miasta. Wytwarzanie miejskiej ikonosfery (Krajewski 2007); pozycja społeczna - Fotografia. Dyletanci, amatorzy i artyści (Ferenc 2004a); opór - Obraza na obrazy. Strategie spotecznego oporu wobec obrazów dominujących (Drozdowski 2007); logika dyskursu a logika praktyki - Nieprzekładalność naukowego i potocznego dyskursu o fotografii (Ferenc 2006a); bieda - Sztuka fotografowania biedy — komu stuża zdjęcia nędzy (Ferenc 2005); starość - Patrząc na starość. Kultura wizualna starości (Jakubowska, Raciniewska, Rogowski, w druku); internet - Obrazy w sieci. Socjologia i antropologia ikonosfery internetu (Ferenc, Olechnicki 2008); fotoblogi - Pamiętnik z opcja przekazu. Fotografia, fotoblogi i fotoblogerzy w kulturze konsumpcyjnej (Olechnicki, w druku); przedmioty — Fotografie jako przedmioty (Krajewski 2008).

14 Oczywiście celem kilku poniższych akapitów nie jest odrzucenie propozycji Olechnickiego czy Ferenca; przeciwnie, w wielu miejscach pokrywają się one z tym, o czym będzie tu mowa. Przywołujemy Mitchella, żeby lepiej wyłuskać niektóre obszary refleksji nad kulturą wizualną, eksponując przede wszystkim refleksję nad widzeniem, która w propozycji obu autorów znajduje się w cieniu innych rozważań.
} 
William J. T. Mitchell 15, autor, który w centrum - może lepiej „u podstaw” - swoich rozważań stawia nie obraz, ale widzenie. Na czym miałyby polegać wspominane „błędy”, i w konsekwencji, „wizualność”, a nie „obrazowość” socjologii wizualnej?

Zacznijmy od tego, że Mitchell traktuje wizualność jako praktyki widzenia świata, które organizują kulturę, przesuwając $\mathrm{w}$ ten sposób akcent $\mathrm{z}$ obrazów na praktyki widzenia (obrazy są konsekwencją widzenia). Swój projekt określa mianem „pokazywania widzenia”, zaznaczając w ten sposób, że chodzi mu przede wszystkim o zerwanie „zasłony swojskości i samoczynności, która spowija doświadczenie widzenia" (Mitchell 2006, s. 274). W swojej analizie kultury wizualnej nie poprzestaje tym samym na badaniu obrazów, wszystko jedno jakich: mentalnych czy utrwalonych na nośnikach, ale wychodzi od badania codziennych praktyk widzenia i pokazywania, co pozwala skoncentrować się nie na znaczeniu i dekodowaniu obrazów, lecz na ich „życiu i namiętnościach" (Mitchell 2006, s. 280).

Łatwo w tym miejscu zauważyć, że tak rozumiana kultura wizualna stała się przedmiotem zainteresowania nauk społecznych już na początku XX wieku, czego genezy można się dopatrywać w zapoczątkowanych w połowie XIX wieku i trwających wciąż na przełomie stuleci procesach społecznych. Przemiany przestrzeni miejskiej (umożliwiające spoglądanie w dal i wzrokowe doświadczanie przestrzeni; por. Berman 2006), procesy urbanizacji i przyrost liczby mieszkańców, wymuszające powstanie nowoczesnych rozwiązań ewidencyjnych (zaprzęgnięto do tego fotografię, która zaczęła służyć jako dokument tożsamości w dokumentach identyfikacyjnych), rozwój kapitalizmu (i wynikający z tego wzrost dostępności towarów, również ich doświadczania wzrokowego na wystawach sklepowych), rozwój nauk przyrodniczych, coraz bardziej uzależniony od wykorzystywania zdjęć, powstanie nieznanego wcześniej pojęcia „czas wolny” (a tym samym konieczność wypracowania form jego spędzania, na przykład rozwój turystyki) - wszystkie te zjawiska wymagały od socjologów reorientacji zainteresowań w kierunku szeroko rozumianego „życia codziennego” i różnych, w dużej mierze wzrokowych, sposobów jego doświadczania.

15 Wybieramy go również dlatego, że przywołanie wszystkich bohaterów ruchu visual culture zdecydowanie wydłużyłoby nasz wywód, niepotrzebnie tym bardziej, że na przykład kultura wizualna w wydaniu Nicholasa Mirzoeffa (1998) nie różni się zbytnio ani od tego, w jaki sposób Olechnicki i Ferenc myślą o kulturze obrazu, którą uczynili podstawą swoich rozważań niemetodologicznych, ani od kierunku myślenia zapoczątkowanym przez opisywane już podejście krytyczne (choć może warto by na tę okazję uzupełnić je jeszcze o Baudrillarda). Podarujemy sobie również rozważania o tym, że już sam termin „socjologia kultury wizualnej” to oksymoron (innymi słowy, namysł nad interdyscyplinarnymi tradycjami i długą listą obszarów badawczych, z których studia nad kulturą wizualną czerpią swoje inspiracje), a także nad klimatem, w których powstały, oraz nad tym, że na kontynencie, w Wielkiej Brytanii i w Stanach Zjednoczonych rozumiane były (i są nadal) zawsze trochę inaczej (na ten temat zob. np. Zeidler-Janiszewska 2006; Bryl 2000; Olechnicki 2003a, s. 93-97). 
Za prekursora takiego podejścia można uznać Georga Simmla, który w swoich licznych „próbach estetycznych” zwracał uwagę na istotne z socjologicznego punktu widzenia cechy zmysłu wzroku, choćby w budowaniu więzi społecznych (Simmel 2006). Co istotne, Simmlowskie refleksje były wynikiem jego własnych obserwacji, co dodatkowo pozwala potraktować go jako doskonały przekład flâneura doświadczającego swojego otoczenia głównie poprzez obserwację wzrokową (takie nastawienie dobrze współgrało z coraz większym upowszechnieniem fotografii, postrzeganej jako doskonałe odbicie idei nowoczesności; zob. np. Rouille 2007, s. 21-61 i 107-154). Kontynuatorami takiej tradycji byli, z jednej strony, Benjamin, który na długo przed Mitchellem włączył w obszar refleksji nad wizualnością rozważania nad mediami i próbę odpowiedzi na pytanie, $w$ jaki sposób zmieniają one dotychczasowe praktyki widzenia i w konsekwencji społeczną organizację, z drugiej strony, Goffman, który bliższy Simmlowi - dużo bardziej niż rolą mediów w zapośredniczeniu relacji społecznych zainteresowany był wizualnym wymiarem codziennych interakcji.

Wróćmy jednak do Mitchella. Uznaje on oczywiście założenie o społecznej konstrukcji widzenia (to ono w ogóle umożliwiło visual studies), jednocześnie podkreśla jednak, że kiedy staje się ono niepodważalnym dogmatem, może uczynić tyle samo szkody co traktowanie widzenia i obrazów jako form kulturowo niezapośredniczonych (Mitchell 2006, s. 281). Dlatego formułuje chiastyczną tezę o wizualnej konstrukcji tego, co społeczne, i poleca w tej kwestii myślenie dialektyczne: „nie jest po prostu tak, że widzimy tak, jak widzimy, ponieważ jesteśmy zwierzętami społecznymi, ale jest również tak, że nasze społeczne formy organizacyjne przybierają taką formę jaką przybierają, ponieważ jesteśmy zwierzętami widzącymi" (Mitchell 2006, s. 282).

Takie postawienie sprawy nie tylko każe pytać o to, co w widzeniu niekulturowe (przywracając w zakres rozważań nad wizualnością fizjologię i psychologię percepcji), ale przede wszystkim zwraca uwagę, że nie jest tak, że nasza kultura podporządkowana jest widzeniu, ponieważ tworzymy/posługujemy się/sugerujemy się utrwalonymi obrazami, ale — zupełnie na odwrót robimy to wszystko, ponieważ nasza kultura jest wzrokocentryczna. Popularność obrazów w kulturze jest zatem wobec niej wtórna i choćby dlatego nie warto stawiać ich w centrum; tym bardziej tylko z tego powodu, że dzisiaj wydaje się nam, iż jest ich więcej, niż było kiedyś. Kultura pojmowana wizualnie tym by się różniła od kultury obrazu, że w pierwszej kolejności organizowana jest przez widzenie, a nie przez obraz.

Prymat widzialnego okazuje się w ten sposób „fundamentalnym składnikiem ludzkich kultur jako takich", a nie nowoczesnym wynalazkiem, wyprodukowanym przez nowe media (Mitchell 2006, s. 283). Nie można zatem poprzestawać na założeniu, że media techniczne po prostu są centralne dla kultury wizualnej. W pierwszej kolejności należy odpowiedzieć na pytanie, dlaczego stały się centralne, czyli w jaki sposób zaadaptowały się do sposobów, w jakie widzimy i jak je zmieniły, żeby potem móc się zastanowić również nad tym, jak 
taka zmiana $\mathrm{w}$ widzeniu przekłada się na zmiany w społecznej organizacji (zarówno na poziomie makro, jak i mikro) ${ }^{16}$. Innymi słowy, wielką zaletą myślenia Mitchella jest to, że każe pytać, w jaki sposób i w jakich miejscach rzeczywistość społeczna przybiera nowe formy wymuszone zmianą w sposobie jej widzenia, a w konsekwencji - jak obrazy (również mentalne) tej rzeczywistości podtrzymują i przekształcają szeroko rozumiane instytucje społeczne/sposoby organizowania wspólnot. Co byłoby jednocześnie odpowiedzią na pytanie, dlaczego i gdzie ich potrzebujemy, czyli co sprawia, że są popularne.

„Zwrot piktorialny” okazuje się wtedy nie tyle wskaźnikiem wyjątkowości naszych czasów, które miałyby się charakteryzować obsesją widzenia i reprezentacji, ale przede wszystkim — jak mówi Mitchell (2006, s. 286) — „powracającym tropem", powtarzalnym od Antyku wielokrotnie. Każda kultura jest wizualna i nawet jeżeli przyznamy, że współcześnie przybrała wysoce specyficzną postać, to zamiast budować binarny model historii, powinniśmy raczej wykorzystać figurę „zwrotu piktorialnego” jako diagnostyczne narzędzie analityczne, pomocne w badaniu „tych właśnie szczególnych momentów, gdy nowe medium, wynalazek techniczny lub kulturowa praktyka wywołują symptomy paniki lub euforii (zazwyczaj oba) w dziedzinie «tego, co wizualne»" (Mitchell 2006, s. 286). Kultura wizualna trwa dzięki zdolności widzenia, a nie dzięki konkretnym obrazom, które w określonych momentach historycznych zwracają na siebie uwagą. Zauważmy też, że jeżeli niektóre obrazy mają zdolność długiego trwania, czyli wykraczają poza życie jednostki, to jest tak dlatego, że takie trwanie zawdzięczają zewnętrznym wobec niej nośnikom. Podobnie zatem jak nie ma kultury-nie-wizualnej, tak nie ma też kultury-tylko-wizualnej.

Dlatego w analizie kultury wizualnej nie pomaga nazywanie jakichkolwiek mediów „wizualnymi”. I to nie tylko dlatego, że przywykliśmy do traktowania ich jako wskaźnika technologicznej współczesności, ale przede wszystkim ze względu na to, że taki język oddala refleksję nad częścią ram kulturowych, w które wplecione są obrazy. Zdaniem Mitchella, wszystkie media są mieszane, wszystkie, a więc również kino czy internet. Myślenie o mediach „mieszanych” w miejsce „wizualnych" ma zatem tę zaletę, że pozwala zerwać z „reifikacją mediów wokół pojedynczego organu zmysłowego (lub pojedynczego typu znaku, czy też materialnego nośnika) i naprawdę skoncentrować się na przedmiocie, który mamy przed sobą" (Mitchell 2006, s. 280). Badając fotografię czy telewizję, czy cokolwiek z domeny wizualności, musimy więc przynajmniej pamiętać, że kontakt $z$ mediami (tak jak z całą kultura) ma charakter polisensoryczny. Dopiero takie ujęcie pozwala odpowiedzieć na pytanie, w jaki sposób jednostki na co dzień przeżywają/wytwarzają — jeszcze lepiej „odgrywają” — wizualność.

16 Na przykład — ciężko byłoby na poważnie analizować „kulturę transparencji” (zob. Krajewski 2005) albo wpływ mediatyzacji kontaktów face-to-face na interakcje (zob. np. Horton, Wohl 1997), gdyby pominąć w tych analizach widzenie jako mechanizm społecznej organizacji. 
Taki sposób myślenia o mediach jest u Mitchella mocno powiązany z rozważaniami na temat charakteru władzy, którą sprawują nad nami obrazy. Popularną opinię, którą formułuje on w następujący sposób: „widzenie i obrazy wyrażają relacje władzy, w których widz dominuje nad przedmiotem wizualnym, a obrazy i ich wytwórcy egzekwują władzę nad widzami”, nazywa „błędem władzy" (Mitchell 2006, s. 284). Oczywiście Mitchell nie ma wątpliwości co do tego, że obrazy mogą być instrumentem dominacji (w czym zresztą niczym nie różnią się, jego zdaniem, od kultury oralnej czy materialnej), ale wcale nie przeszkadza to $\mathrm{w}$ traktowaniu ich jako czegoś więcej. Warto zwrócić uwagę, że ich podstawową funkcją rzadko kiedy bywa ideologiczna indoktrynacja; służą i są popularne przede wszystkim dlatego, że pomagają tworzyć wspólnoty. W dodatku nie są też do końca posłuszne żadnemu „celowi”, ponieważ potrafią wyznaczać cele „własne”. Dlatego bardziej uzasadnione jest, zdaniem Mitchella (2006, s. 288), przyjęcie, że obraz jest zarówno narzędziem poddającym się manipulacji, jak i źródłem autonomicznego celu i znaczenia.

Trwać w błędzie „władzy” to uznawać oglądających za biernych konsumentów, podczas gdy wiele wskazuje na to, że w swoim odbiorze są zdecydowanie bardziej twórczy („kłusują”, odwołując się do terminologii de Certeau; 2008). To również ignorować fakt, że obrazy sprawują nad nami kontrolę przede wszystkim niejako samą swoją obecnością (Gell 1998). W ten sposób domagają się, żeby coś z nimi zrobić, mają własne afordancje - ze względu na swój kształt i polisemiotyczny charakter po prostu stawiają opór niektórym wykorzystaniom, lepiej nadając się do innych. Obrazy są nie tylko przekazami, ale również rzeczami, z którymi - no właśnie - robi się różne rzeczy. Posługujemy się nimi bardziej niż recypujemy.

Obrazy nie zjawiają się zatem bezcieleśnie, bez nośnika, który sprawia, że stają się artefaktem (nośnikiem może być też ciało; Belting 2007). Tym samym każdy kontakt wizualny jest — w mniejszym czy większym stopniu również kontaktem z przedmiotem i jego materialnością. Co więcej, to właśnie nośnik sprawia, że obrazy mają swoje „kariery”, i że - jak mówi Mitchell (2006, s. 290) — „mają swoje własne życie”. Taki sposób myślenia o obrazach doprowadza go do znanego stwierdzenia, że lepiej pytać nie o to, co obrazy znaczą lub robią, ale „co jest sekretem ich żywotności” i „czego one chcą” (więcej na ten temat zob. Krajewski 2008).

To ostatnie zdanie można rozumieć jeszcze bardziej metaforycznie — obraz jest pośrednikiem w interakcji na każdym poziomie, również na tym najbardziej podstawowym: $w$ interakcji $z$ Innym. Kulturowy obraz Innego, warunkowany spojrzeniem, można zrozumieć jako pośrednictwo, które umożliwia kontakt, i jako taki stanowi on źródło każdego społeczeństwa (Raymond Williams, za: Mitchell 2006, s. 289). Dlatego też, idąc dalej za wskazówkami Mitchella, najlepiej traktować kulturę wizualną i obrazy jako „posłańców w społecznych transakcjach, jako repetytorium obrazów lub szablonów wizualnych, które strukturyzują nasze spotkania z innymi istotami ludzkimi" (Mitchell 2006, s. 289). 
Trudno o potężniejszy argument, który mógłby przekonać socjologa, że widzenie jest warte namysłu. Tym bardziej socjologa wizualnego, jeżeli uznamy, że powinien on brać pod uwagę wszystko to, co czyni kulturę wizualną elementem życia społecznego.

\section{SOCJOLOGIA BARDZIEJ WIZUALNA}

Nasze rozważania koncentrują się tu wokół trzech głównych zagadnień nauk społecznych, fotografii oraz kultury wizualnej. Wskazane przez nas tropy, łączące te trzy obszary, składają się na bardzo szeroki kontekst, w którym umiejscowić można socjologię wizualną. Oczywiście, nie było naszym zadaniem mnożenie inspiracji, definicji, przykładów i często sprzecznych ze sobą sposobów wyznaczania relacji między naukami społecznymi, fotografią i wizualnością (celowo pominęliśmy choćby refleksję psychoanalityczną i medioznawcza). Mogliśmy natomiast ujawnić historyczną zmienność omawianych relacji, która - jak staraliśmy się to pokazać - wynika z ogólniejszych tendencji występujących we wszystkich trzech wspomnianych obszarach. Dzięki temu możliwe staje się dodatkowe oświetlenie tematu, zarówno przez wskazanie głównego nurtu łączącego omawiane pola (a tym samym nurtów wobec niego pobocznych), jak i próbę zarysowania miejsca, w którym socjologia wizualna znajduje się obecnie.

Wydaje się przy tym, że polska socjologia wizualna wymaga jasnego i precyzyjnego określenia dalszych dróg rozwoju, a może to uczynić wyłącznie przez zdefiniowanie samej siebie w relacji do socjologii ogólnej (również przez wpisanie się we „wspólną” historię socjologii). Jeżeli bowiem w dalszym ciągu socjologia wizualna będzie traktowana wyłącznie jako zasada ilustracyjno-metodologiczna - jak wciąż dzieje się $\mathrm{w}$ wielu przypadkach - w niedługim czasie jej znaczenie może stać się podobne do tego, jakie dla badań ilościowych ma obecnie pojęcie „socjologia ankietowa”. Natomiast redukowanie refleksji nad kulturą wizualną do przysłowiowych semiologicznych śledztw (szukania „ukrytych interesów rynku i władzy”) może sprawić, że jej przedmiot rozpuści się $\mathrm{w}$ socjologii kultury i socjologii władzy, znikając szybko jako jednorazowe odkrycie faktu, że władza kapilarna realizuje się wszędzie, a więc również w obrazach (na takie ryzyko zwracają uwagę Drozdowski, Krajewski; np. 2007).

To właśnie $z$ tego powodu bardzo optymistyczny jest dostrzegany w ciągu ostatnich 3-4 lat fakt wypracowywania przez polską socjologię wizualną specyfiki, nie zawsze zgodnej z tendencjami, które da się zaobserwować w socjologii zagranicznej. Specyficzność ta wynika na przykład z prób łączenia teorii i warsztatu socjologa z koncepcjami teoretyczno-pojęciowymi wypracowywanymi w szeroko rozumianych studiach nad kulturą wizualną.

Główną charakterystyką owego powiązania staje się przekonanie, że każda kultura jest wizualną konstrukcją tego, co społeczne, i że wszelki obraz (men- 
talny, artystyczny, fotograficzny, interakcyjny itd.) jest społeczną konstrukcją tego, co wizualne (Mitchell 2006). Nie jest więc niezależnym podmiotem, ale wypadkową różnego rodzaju czynników i sieci uwikłań (biologicznych, psychologicznych, społecznych, kulturowych, technologicznych), które ścierają się w jednostce/grupie. Tak jak widzenie jest procesem biologicznym, tak oglądanie jest sposobem angażowania się w kulturę i łączy w sobie wszystkie wymienione czynniki. Oglądanie jest zatem czynnością społeczną, strukturyzującą społeczeństwo we współpracy z ideologią, gospodarką i kulturą materialną (i w podobnym stopniu jak one); dlatego też nie należy go utożsamiać z obrazem.

Celem socjologii wizualnej nie powinno być zatem uporczywe dążenie do samodzielności badań; zwłaszcza gdy zrezygnujemy $z$,wizualnego esencjalizmu", czyli odrzucimy pogląd o prymarnie wizualnej naturze współczesnej kultury, a także ten, że kultura wizualna jest segmentem kultury, dającym się wydzielić z jakiejś całości (Bal 2006, s. 296). Jeżeli zgodzimy się, że wizualność, jakkolwiek wpleciona w szersze mechanizmy reprodukowania kultury, to jednak wytwarzana jest w codziennych interakcjach, czyli że wchodzi w treść potocznych praktyk, podejmowanych przez różne podmioty, w różnych kontekstach, przy okazji różnych czynności, w których wymiar wizualny jest tylko jednym $z$ wielu, to wtedy nie powinniśmy też zapominać, że socjologia wizualna może czerpać pełnymi garściami nie tylko $z$ dorobku teoretyków fotografii i przedstawicieli visual culture, ale też z innych socjologii.

W tym sensie socjologia wizualna zmierza, bardziej niż do stania się jakościowo nową dyscypliną, raczej w kierunku wzbogacenia i poszerzenia zainteresowań i teorii istniejących $\mathrm{w}$ tradycyjnie rozumianej socjologii. Właśnie $z$ tych powodów Grady (2007, s. 70) zamiast o socjologii „po prostu” wizualnej woli mówić o socjologii „bardziej” wizualnej. Relacja między tak rozumianą socjologią wizualną a socjologią ogólną, pojmowaną nie tylko jako zbiór przedmiotów i sposobów badania, ale również jako pewien typ mentalności (Geertz 2005, s. 163), wyglądałaby zatem bardzo prosto. Skoro socjologia wizualna to tyle, co metody wykorzystywane $\mathrm{w}$ procesie badawczym, również do komunikowania wyników, oraz refleksja nad kulturą wizualną — w zakresie, w jakim w obu tych rolach pomaga odpowiedzieć na już istniejące $\mathrm{w}$ socjologii pytania dotyczące społeczeństwa oraz formułować nowe - to z tych właśnie zadań należałoby ją rozliczać.

O ile zatem wyodrębnienie wizualności jako przedmiotu badań ma w pierwszej kolejności znaczenie retoryczne - chodzi o proste wskazanie, że wizualność wymaga refleksji socjologicznej, o tyle później chodzi o to, żeby uwzględniać wymiar wizualny nie tylko w badaniach nad fotografia, ale przede wszystkim w badaniach nad społeczeństwem, które in statu nascendi jest przecież wielowymiarowe. Uprawiając socjologię wizualną trzeba się w tym celu nauczyć widzieć przedmiotowy podział socjologii nie jako hierarchię ważności tematów (co pozwala postrzegać samego siebie w wygodnej roli buntownika 
walczącego o zmianę tej hierarchii), ale jako zbiór zagadnień do uwzględnia $\mathrm{w}$ analizie konkretnego zjawiska (Wagner 2006) ${ }^{17}$.

Oczywiście przedstawiona $\mathrm{w}$ tym miejscu koncepcja - oparta na analizie współczesnych tendencji w polskiej socjologii wizualnej - ma charakter wyraźnie postulatywny. Każdy może zadać pytania „a dlaczego tak?”, „a dlaczego nie w inny sposób?". Pewnym usprawiedliwieniem może być fakt, że przedstawiliśmy tu różne drogi ku temu, co nazywamy socjologią wizualną. Analiza tych dróg, a zwłaszcza ostatnich publikacji, pozwala na pokuszenie się o swoisty futuryzm, podszyty jednak pewną logiką. W jakim stopniu się on sprawdzi — nie wiadomo, trzeba będzie zapytać za kolejne dziesięć lat.

\section{BIBLIOGRAFIA}

Adair John, Worth Sol, 1972, Through Navajo Eyes: An Exploration in Film Communication and Anthropology, Indiana University Press, Bloomington.

Bal Mieke, 2006, Wizualny esencjalizm i przedmiot kultury wizualnej, tłum. Mariusz Bryl, „Artium Quaestiones”, t. XVII, s. 295-333.

Bateson Gregory, Mead Margaret, 1942, Balinese Character: A Photographic Analysis, New York Academy of Sciences, New York.

Becker Howard S., 1974, Photography and Sociology, „Studies in the Anthropology of Visual Communication", t. 1, nr 1, s. 3-26.

Belting Hans, 2007, Antropologia obrazu. Szkice do nauki o obrazie, tłum. Mariusz Bryl, Universitas, Kraków.

Benjamin Walter, 1996 [1936], Dzieło sztuki w dobie reprodukcji technicznej, tłum. Janusz Sikorski, w: Walter Benjamin, Anioł historii. Eseje, szkice, fragmenty, Wydawnictwo Poznańskie, Poznań.

Berger John, Mohr Jean, 1995, Another Way of Telling, Pantheon, New York.

Berman Marshall, 2006, Wszystko, co stałe, rozptywa się w powietrzu. Rzecz o doświadczaniu nowoczesności, tłum. Marcin Szuster, Universitas, Kraków.

Bloch Ernst, 1985 [1935], Erbschaft dieser Zeit, Suhrkamp, Frankfurt am Main.

Bourdieu Pierre, 1990 [1965], Photography: A Middle-brow Art, thum. Shaun Whiteside, Stanford University Press, Stanford.

Bryl Mariusz, 2000, Historia sztuki na przejściu od kontekstowej Funktionsgeschichte ku antropologicznej Bildwissenschaft (casus Hans Belting), „Artium Quaestiones”, t. XI, s. 237-295 .

Busza Jerzy, 1981a, Wobec fotografii, Centralny Ośrodek Metodyki Upowszechniania Kultury, Warszawa.

Busza Jerzy, 1981b, Wobec fotografów, Centralny Ośrodek Metodyki Upowszechniania Kultury, Warszawa.

Busza Jerzy, 1990, Wobec odbiorców fotografii, Centralny Ośrodek Metodyki Upowszechniania Kultury, Warszawa.

17 Dobrym przykładem takiego myślenia może być Spojrzenie turysty Johna Urry’ego (2007). Książka, w której wizualność traktowana jest jako jeden $z$ wymiarów analizowanego zjawiska i zestawiona między innymi z wątkami dotyczącymi interakcji, uwarunkowań gospodarczych i kulturowych — takie zestawienie sprawia, że wymienione wymiary wzajemnie się wyjaśniają. 
Certeau Michel de, 2008, Wynaleźć codzienność. Sztuki działania, tłum. Katarzyna Thiel-Jańczuk, Wydawnictwo Uniwersytetu Jagiellońskiego, Kraków.

Chaplin Elizabeth, 1994, Sociology and Visual Representation, Routledge, London-New York.

Collier John Jr, 1957, Photography in Anthropology: A Report on Two Experiments, „American Anthropologist", t. 59, s. 843-859.

Collier John Jr, 1979a, Evaluating Visual Data, w: Jon Wagner (red.), Images of Information: Still Photography in the Social Sciences, Sage, Beverly Hills-London.

Collier John Jr, 1979b, Visual Anthropology, w: J. Wagner (red.), Images of Information: Still Photography in the Social Sciences, Sage, Beverly Hills-London.

Collier John Jr, Collier Malcolm, 1986, Visual Anthropology: Photography as a Research Method, University of New Mexico Press, Albuquerque.

Crilly Nathan, Blackwell Alan F., Clarkson John, 2006, Graphic Elicitation: Using Research Diagrams as Interview Stimuli, „Qualitative Research”, t. 6, s. 341-366.

Czachowski Hubert, 2004, Antropologia obrazu — skąd przybywa i dokąd zmierza? Uwagi na marginesie dwóch książek i wielu obrazów, „Kultura i Społeczeństwo”, nr 4.

Czartoryska Urszula, 1965, Przygody plastyczne fotografii, Wydawnictwa Artystyczne i Filmowe, Warszawa.

Czartoryska Urszula, 1981a, Eseistyka Rolanda Barthesa o paradoksie i szaleństwie fotografii, „Fotografia”, nr 1, s. 1-3.

Czartoryska Urszula, 1981b, W kręgu teorii Benjamina, „Fotografia”, nr 3-4.

Czartoryska Urszula, 2007, Fotografia - mowa ludzka. Perspektywy historyczne, Słowo/ obraz terytoria, Gdańsk.

Drozdowski Rafał, 2004, Socjologie wizualne i ich dylematy, w: Jerzy Kaczmarek (red), Kadrowanie rzeczywistości. Szkice z socjologii wizualnej, Wydawnictwo Naukowe UAM, Poznań.

Drozdowski Rafał, 2006, Otwarta Baza Danych Wizualnych, w: Jerzy Kaczmarek, Marek Krajewski (red.), Co widać?, Wydawnictwo Naukowe UAM, Poznań.

Drozdowski Rafał, 2007, Obraza na obrazy. Strategie społecznego oporu wobec obrazów dominujących, Wydawnictwo Naukowe UAM, Poznań.

Drozdowski Rafał, Krajewski Marek, 2007a, Czego nie widzimy, a co można zobaczyć uważnie się przygladajac (zdjęciom)?, w: Rafał Drozdowski (red.), Końce i poczattki. Socjologiczne posumowanie, socjologiczne zapowiedzi, Wydawnictwo Naukowe UAM, Poznań.

Drozdowski Rafał, Krajewski Marek (red.), 2008, Wyobraźnia społeczna. Horyzonty — źródła - dynamika. Uwarunkowania strategii dostosowawczych wspótczesnego spoteczeństwa polskiego — studium socjologiczne, Wydawnictwo Naukowe UAM, Poznań.

Emmison Michael, Smith Philip, 2000, Researching the Visual: Images, Objects, Contexts and Interaction in Social and Cultural Inquiry, Sage, London-Thousand Oaks-New Delhi.

Ferenc Tomasz, 2001, Socjologia obrazu, socjologia fotografii — praktyki badawcze, „Przegląd Socjologiczny", nr 2, s. 81-99.

Ferenc Tomasz, 2004a, Między koncepcją świadectwa a ideologicznym uwikłaniem fotografi, „Kultura i Społeczeństwo”, nr 1.

Ferenc Tomasz, 2004b, Fotografia. Dyletanci, amatorzy i artyści, Galeria f5 \& Księgarnia fotograficzna, Łódź.

Ferenc Tomasz, 2005, Sztuka fotografowania biedy — komu stuża zdjęcia nędzy?, „Kultura i Społeczeństwo", nr 4.

Ferenc Tomasz, 2006a, Nieprzekładalność naukowego i potocznego dyskursu o fotografii, „Przegląd Socjologiczny", nr 2. 
Ferenc Tomasz (red.), 2006b, Odwaga patrzenia. Eseje o fotografii, Wydawnictwo Fundacji Edukacji Wizualnej, Łódź.

Ferenc Tomasz, Kowalewicz Kazimierz, 2009, Interpretując fotografię. Śladami Susan Sontag, Galeria f5 \& Księgarnia Fotograficzna, Kraków.

Ferenc Tomasz, Makowski Krzysztof (red.), 2005, Przestrzenie fotografii. Antologia tekstów, Galeria f5 \& Księgarnia fotograficzna, Łódź.

Ferenc Tomasz, Olechnicki Krzysztof (red.), 2008, Obrazy w sieci. Socjologia i antropologia ikonosfery Internetu.

Ferenc Tomasz, Studzińska Joanna (red.), 2007, Światto i mrok. Eseje o fotografii hiszpańskiej, Wydawnictwo Fundacji Edukacji Wizualnej, Łódź.

Ferenc Tomasz, Sułkowski Bogusław, 2004, Fotografia i telenowela — dwa przykłady konstruowania rzeczywistości, „Kultura i Społeczeństwo”, nr 4.

Flusser Vilém, 2004, Ku filozofii fotografii, tłum. Jacek Maniecki, Akademia Sztuk Pięknych, Katowice.

Garztecki Juliusz, 1977, Fotografia rodzinna, Wydawnictwo Artystyczne i Filmowe, Warszawa.

Garztecki Juliusz, 1981, Zarys dziejów fotografii spotecznej, „Fotografia”, nr 2.

Geertz Clifford, 2005, Wiedza lokalna. Dalsze eseje z zakresu antropologii interpretatywnej, tłum. Dorota Wolska, Wydawnictwo Uniwersytetu Jagiellońskiego, Kraków.

Gell Alfred, 1998, Art and Agency: An Anthropological Theory, Clarendon Press, Oxford.

Goffman Erving, 1979, Gender Advertisements, Harvard University Press, Cambridge.

Grady John, 1998, Towards a quantitative social science, „Visual Studies”, t. 13, nr 1, s. 74-84 .

Grady John, 2006, Edward Tufte and the Promise of a Visual Social Science, w: Luc Pauwels (red.), Visual Cultures of Science: Rethinking Representational Practices in Knowledge Building and Science Communication, University Press of New England, Lebanon.

Grady John, 2007, Visual Sociology, w: Clifton D. Bryant, Dennis L. Peck, $21^{\text {st }}$ Century Sociology: Specialty Fields, Sage, Thousand Oaks.

Grady John, 2009, Badania wizualne na rozdrożu, „Przegląd Socjologii Jakościowej”, t. 5, nr 2.

Harper Douglas, 1986, Working Knowledge, University of Chicago Press, Chicago.

Harper Douglas, 2005, What's New Visually?, w: Norman K. Denzin, Yvonna S. Lincoln (red.), The Sage Handbook of Qualitative Research (3rd ed.), Sage, Thousand Oaks.

Henny Leonard M., 1986, Trend Report: Theory and Practice of Visual Sociology, „Current Sociology", t. 34, nr 3.

Herudziński Tomasz, 2006, O sposobach rozumienia socjologii wizualnej, w: Jerzy Kaczmarek, Marek Krajewski (red.), Co widać?, Wydawnictwo Naukowe UAM, Poznań.

Horton Donald, Wohl Richard R., 1997, Komunikacja masowa i paraspoteczna interakcja. Uwagi o intymności na odległość, tłum. Artur Piskorz, w: Andrzej Gwóźdź (red.), Pejzaże audiowizualne. Telewizja - wideo - komputer, Universitas, Kraków.

Jakubowska Honorata, Raciniewska Alicja, Rogowski Łukasz (red.), w druku, Patrzac na starość. Kultura wizualna starości.

Kaczmarek Jerzy, 2002, Poznań $w$ fotografii $i$ świadomości swoich mieszkańców, „Przegląd Zachodni", t. 58, s. 48-60.

Kaczmarek Jerzy (red.), 2004, Kadrowanie rzeczywistości. Szkice z socjologii wizualnej, Wydawnictwo Naukowe UAM, Poznań.

Kaczmarek Jerzy (red.), 2008, Do zobaczenia. Socjologia wizualna w praktyce badawczej, Wydawnictwo Naukowe UAM, Poznań. 
Kaczmarek Jerzy, Krajewski Marek (red.), 2006, Co widać?, Wydawnictwo Naukowe UAM, Poznań.

Knowles Carolina, Sweetman Paul (red.), 2004, Picturing the Social Landscape: Visual Methods and the Sociological Imagination, Routledge, London.

Konecki Krzysztof T., 2005a, Ludzie $i$ ich zwierzęta. Interakcjonistyczno-symboliczna analiza społecznego świata wtaścicieli zwierząt domowych, Scholar, Warszawa.

Konecki Krzysztof T., 2005b, Wizualne wyobrażenia. Główne strategie badawcze w socjologii wizualnej a metodologia teorii ugruntowanej, „Przegląd Socjologii Jakościowej”, t. 1, nr 1.

Konecki Krzysztof T., 2008, Wizualna Teoria Ugruntowana. Rodziny kodowania wykorzystywane $w$ analizie wizualnej, „Przegląd Socjologii Jakościowej”, t. 4, nr 3.

Koseła Krzysztof, 1989, Wywiad z interpretacja fotogramów, w: Antoni Sułek, Anna Wyka (red.), Poza granicami socjologii ankietowej, Instytutu Socjologii UW, Warszawa.

Koseła Krzysztof, 1990, Interpretacja fotografii - krok ku socjologii wizualnej, „Kultura i Społeczeństwo", nr 1.

Kracauer Siegfried, 1958 [1947], Od Caligariego do Hitlera: z psychologii filmu niemieckiego, tłum. Eugenia Skrzywanowa, Wanda Wertenstein, Filmowa Agencja Wydawnicza, Warszawa.

Krajewski Marek, 1999, Medialna kultura moratorium. Nowoczesność i tradycja $w$ polskich reklamach telewizyjnych, „Kultura i Społeczeństwo”, nr 3.

Krajewski Marek, 2005, Kultury kultury popularnej, Wydawnictwo Naukowe UAM, Poznań.

Krajewski Marek (red.), 2007, Wizualność miasta. Wytwarzanie miejskiej ikonosfery, Wydawnictwo Naukowe UAM, Poznań.

Krajewski Marek, 2008, Fotografie jako przedmioty, w: J. Kaczmarek (red.), Do zobaczenia. Socjologia wizualna $w$ praktyce badawczej, Wydawnictwo Naukowe UAM, Poznań.

Ligocki Alfred, 1979, Fotograficzne penetracje, Wydawnictwo Literackie, Kraków.

Ligocki Alfred, 1987, Czy istnieje fotografia socjologiczna?, Wydawnictwo Literackie, Kraków.

Magala Sławomir, 1978, Fotografia jako element teatralizacji życia społecznego, „Fotografia”, nr 4.

Magala Sławomir, 1979, Konstrukcja przestrzeni społecznej $w$ fotografii, „Fotografia”, nr 3.

Magala Sławomir, 1982, Fotografia w kulturze wspótczesnej, Centralny Ośrodek Metodyki Upowszechniania Kultury, Warszawa.

Magala Sławomir, 2000, Szkoła widzenia, czyli świat $w$ subiektywie aparatu fotograficznego, Biblioteka Formatu, Wrocław.

Michałowska Marianna, 2004, Niepewność przedstawienia, Rabid, Poznań.

Michałowska Marianna, 2005, Z soboty na niedziele — dokument fotograficzny i portrety życia miejskiego, „Kultura i Społeczeństwo”, nr 1.

Michałowska Marianna, 2007, Obraz utajony. Szkice o fotografii i pamięci, Galeria f5 \& Księgarnia fotograficzna, Łódź.

Michałowska Marianna, 2008, Przestrzeń i pustka. Fotografia jako poszukiwanie tożsamości, w: Monika Kozień-Świca, Marta Miskowiec (red.), Rzeczywistość a dokument, Muzeum Historii Fotografii, Kraków.

Mirzoeff Nicholas (red.), 1998, Visual Culture Reader, Routledge, London-New York.

Mitchell William J. T., 2006, Pokazując widzenie: krytyka kultury wizualnej, tłum. Mariusz Bryl, „Artium Quaestiones”, t. XVII, s. 273-295. 
Olechnicki Krzysztof, 1999, Obraz i wizualność w naukach społecznych, „Kultura i Społeczeństwo", nr 3.

Olechnicki Krzysztof, 2000, Antropologiczne penetracje wizualnych przestrzeni rzeczywistości: fotografia jako narzędzie badawcze, „Kultura i Społeczeństwo”, nr 4.

Olechnicki Krzysztof, 2003a, Antropologia obrazu. Fotografia jako metoda, przedmiot i medium nauk spotecznych, Oficyna Naukowa, Warszawa.

Olechnicki Krzysztof (red.), 2003b, Obrazy w działaniu. Studia z socjologii $i$ antropologii obrazu, Wydawnictwo UMK, Toruń.

Olechnicki Krzysztof, w druku, Pamiętnik z opcją przekazu. Fotoblogi i fotoblogerzy w kulturze konsumpcyjnej.

Olechnicki Krzysztof, Szlendak Tomasz, 2002, Wywiad z użyciem fotografii w metodologii badań socjologicznych i praktyce społecznej, „Ask”, nr 11, s. 7-26.

Pauwels Luc, 2000, Taking the Visual Turn in Research in Scholarly Communication, „Visual Studies", t. 15, nr 1-2, s. 7-14.

Panek-Sarnowska Barbara, 2005, Socjologiczność fotografii Zofii Rydet, Lubuskie Towarzystwo Fotograficzne, Zielona Góra.

Rose Gillian, 2001, Visual Methodologies. An Introduction to the Interpretation of Visual Materials, Sage, London.

Rouille Andre, 2007, Fotografia. Między dokumentem a sztuka wspótczesna, tłum. Oskar Hedemann, Universitas, Kraków.

Sikora Sławomir, 2004, Fotografia między dokumentem a symbolem, Świat Literacki, Warszawa.

Simmel Georg, 2006, Most i drzwi. Wybór esejów, tłum. Małgorzata Łukasiewicz, Oficyna Naukowa, Warszawa.

Sztompka Piotr, 2006, Socjologia wizualna. Fotografia jako metoda badawcza, Wydawnictwo Naukowe PWN, Warszawa.

Törronen Jukka, 2002, Semiotic Theory on Qualitative Interviewing Using Stimulus Texts, „Qualitative Research", t. 2, nr 3, s. 343-362.

Urry John, 2007, Spojrzenie turysty, tłum. Alina Szulżycka, Wydawnictwo Naukowe PWN, Warszawa.

Wagner Jon, 2004, Constructing Credible Images: Documentary Studies, Social Research, and Visual Studies, „American Behavioral Scientist”, t. 47, nr 12, s. 1477-1506.

Wagner Jon, 2006, Visible materials, visualised theory and images of social research, „Visual Studies", t. 21, nr 1, s. 55-69.

Zeidler-Janiszewska Anna, 2006, Visual Culture Studies czy antropologicznie zorientowana Bildwissenschaft? O kierunkach zwrotu ikonicznego w naukach o kulturze, „Teksty Drugie”, nr 4.

Ziemilski Andrzej, 1981, Fotografia a warsztat socjologa, „Fotografia”, nr 2.

\section{IN SEARCH OF POLISH VISUAL SOCIOLOGY}

\section{Summary}

The article aims to sum up the reflections concerning visual culture and the visual aspect of life that have appeared in Polish sociology over the last twenty years as well as to analyse the area associated today with visual sociology. The authors give a short review of the history of Polish visual sociology, indicating at the beginning the most 
essential scientific and didactic events in this field. Further on, they analyse the ways of understanding the notion "visual sociology" (and its cognate notions). They present the use of photography in anthropology and in social research, and give a critical analysis of the studies and representation of visual culture at the beginning of the $20^{\text {th }}$ century. This leads them to the designation of two scopes of the contemporary notion of visual sociology: a more narrow (methodological) one and a broader one (which they call: "the sociology of visual culture"). In all, this analysis shows the ways in which the term "visual sociology" (and its cognate terms) has been gradually adopted, developed and re-defined in Poland.

\section{Key words/słowa kluczowe}

history of sociology / historia socjologii; visual sociology / socjologia wizualna; visual culture / kultura wizualna; photography / fotografia; visual research techniques / wizualne techniki badawcze; sociology of visual culture / socjologia kultury wizualnej 